\title{
Mobilidade nos centros urbanos: estudo para implantar ruas completas no centro de João Pessoa, Paraíba, Brasil
}

\author{
Mobility in urban centers: study to implement complete streets in downtown \\ João Pessoa, Paraíba, Brazil
}

Vivianne Lisbethe Bezerra Maropo[a] 고 , José Augusto Ribeiro da Silveira[b] ${ }^{[}$, Ana Gomes Negrão[c] (1), Dimitri Costa Castor[d] (1)

[a] Universidade Federal da Paraíba (UFPB), Centro de Tecnologia, Laboratório do Ambiente Urbano e Edificado (LAURBE), João Pessoa, PB, Brasil

[b] Universidade Federal da Paraíba (UFPB), Centro de Tecnologia, Departamento de Arquitetura e Urbanismo, João Pessoa, PB, Brasil

[c] Universidade Federal da Paraíba (UFPB), Centro de Tecnologia, Programa de Pós-graduação em Arquitetura e Urbanismo (PPGAU), João Pessoa, PB, Brasil

[d] Universidade Federal da Paraíba (UFPB), Departamento de Arquitetura e Urbanismo, Programa de Pósgraduação em Arquitetura e Urbanismo (PPGAU), João Pessoa, PB, Brasil

Como citar: Maropo, V. L. B., Silveira, J. A. R., Negrão, A. G., \& Castor, D. C. (2020). Mobilidade nos centros urbanos: estudo para implantar ruas completas no centro de João Pessoa, Paraíba, Brasil. urbe. Revista Brasileira de Gestão Urbana, 12, e20190145. https://doi.org/10.1590/2175-3369.012.e20190145

\section{Resumo}

O conceito de Ruas Completas origina-se da necessidade de transformar o atual modelo de planejamento urbano das cidades, em que o transporte motorizado individual é considerado o protagonista do espaço público. Atualmente, são lançados inúmeros conceitos que levantam a questão de fazer cidades para pessoas, que tragam benefícios ao meio urbano e ao bem-estar da população, pois o pedestre passa a ser a prioridade no planejamento, e que incentivem o uso de transportes sustentáveis. Este artigo consiste na construção de um diagnóstico quanto aos aspectos físico-espaciais do bairro Centro de João Pessoa, na Paraíba, para, assim, obter conhecimento sobre as peculiaridades e demandas do local, a fim de aplicar os objetivos das Ruas Completas e aferir sua pertinência. Utilizou-se da sintaxe espacial para definição das ruas a serem trabalhadas e, em seguida, dos métodos counting, mapping, photographing e keeping a diary - contando, mapeando, fotografando e mantendo um diário -, que se compatibilizaram no escopo do trabalho e auxiliaram no levantamento mais preciso dos fluxos e comportamentos da população do bairro, viabilizando a elaboração da proposta. Com os resultados, percebeu-se que existe uma série de ruas no Centro que precisam de grandes intervenções a favor dos pedestres e que o bairro necessita de ações que incentivem a ocupação dos lotes vazios/subutilizados com usos mistos e fachadas ativas, para garantir a movimentação do local ao longo do dia.

Palavras-chave: Ruas completas. Planejamento urbano. Mobilidade.

VLBM é arquiteta e urbanista, graduada em Arquitetura e Urbanismo, e-mail: viviannemaropo@gmail.com JARS é arquiteto e urbanista, doutor em Desenvolvimento Urbano, e-mail: joseaugustorsilveira@gmail.com AGN é arquiteta e urbanista, doutora em Arquitetura e Urbanismo, e-mail: agnegrao@hotmail.com

DCC é arquiteto e urbanista, mestre em Arquitetura e Urbanismo, e-mail: dimitricastor@hotmail.com 


\section{Abstract}

The concept of complete streets arises from the need to transform the current urban planning model of cities, where individual motorized transportation is considered the protagonist of the public space. Nowadays, many concepts are launched that raise the question of making cities for people, that bring benefits to the urban environment and the well-being of the population, as pedestrians become the priority in planning, followed by the incentive to use sustainable transport. This paper consists of the elaboration of research about the physical-spatial aspects of downtown João Pessoa/Paraíba, aiming to obtain information about the local demands, to apply the objectives of the Complete Streets and to investigate their pertinence to the area. Spatial syntax was used to define the streets to be worked and the counting, mapping, photographing and keeping diary methods, which were compatible in the scope of the work and assisted in the more accurate survey of the flows and behaviors of the population of the neighborhood, enabling the preparation of the proposal. With the results, it was possible to perceive that there are a series of streets in downtown that need great interventions in favor of pedestrians and that the neighborhood needs actions that encourage the occupation of the empty/underused lots with mixed uses and active façades, to guarantee the movement of the place throughout the day.

Keywords: Complete streets. Urban planning. Mobility.

\section{Mobilidade nos centros urbanos}

Os problemas de mobilidade urbana enfrentados em várias cidades, nos âmbitos nacional e internacional, tendem a ocorrer por causa das políticas baseadas na primazia do transporte motorizado, resultado das suas dinâmicas de expansão urbana, como apontado por Villaça (2001) e Corrêa (1989).

Segundo Negrão \& Silveira (2016), em grande parte das cidades brasileiras, a urbanização da segunda metade do século XX modificou substancialmente os seus tecidos urbanos, a partir de alterações no volume das edificações, dos modos de implantação, das técnicas utilizadas e das disposições e dimensões dos espaços livres, que começaram a indicar uma ruptura temporal e espacial mais veloz. Cidades com a malha urbana concentrada próxima ao núcleo de origem expandiram-se em demasia por meio de uma dinâmica de segregação - autossegregação ou, principalmente, imposta -, resultado de fatores como avanços da indústria automobilística e, especialmente, da especulação imobiliária.

Desta forma, nota-se que o planejamento urbano das cidades brasileiras foi enfocado na inserção de um suposto rápido e livre trânsito dos veículos, expandindo seus sistemas viários por intermédio de avenidas que fogem à escala humana, em muitos casos, tanto pelo transporte público de baixa qualidade quanto pelos muros altos, torres e condomínios fechados (Figueiredo, 2010). Esse planejamento voltado para a inserção de transportes motorizados individuais gera nas cidades o que Silva \& Romero (2015) chamam de Ciclo de Dependência Automotiva (Figura 1), em que o automóvel passa a modelar os espaços públicos, interferindo no planejamento do uso do solo e contribuindo para a estigmatização dos modos sustentáveis de transporte.

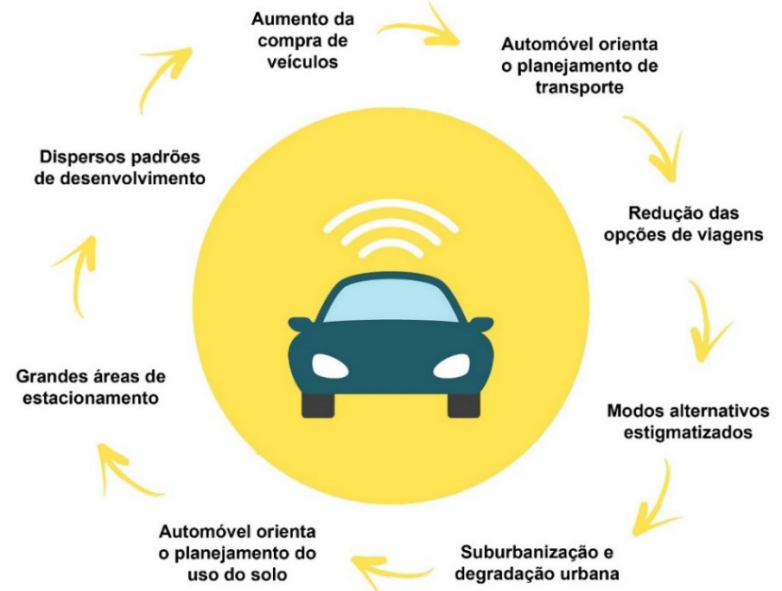

Figura 1 - Ciclo de dependência automotiva. Fonte: Adaptada pelos autores de Silva \& Romero (2015). 
Desde o século XX, autores como Jane Jacobs (2013) apresentaram ideias inovadoras sobre o desenho de cidades em âmbito do pedestre, encorajando os cidadãos a apropriarem-se das ruas e delineando elementos-chave para criar uma vida social vibrante em espaços públicos. Porém, apenas no início do século XXI, pôde-se notar o aumento da preocupação mais enfocada na dimensão humana. A ideia de cidades mais seguras, ativas e sustentáveis tornou-se um desejo universal, reforçando a necessidade de intervenções urbanas e políticas que motivem os moradores a caminhar, pedalar e usar transportes coletivos (Gehl, 2013; Speck, 2017; Karssenberg et al., 2015).

Este trabalho surge da inquietação de propor alternativas para suavizar o problema de mobilidade urbana na área central de João Pessoa, na Paraíba, criando possibilidades para que diversos modos de transporte se integrem à cidade de forma mais democrática, acessível e segura. Portanto, visa à análise do seu atual modelo de ocupação e mobilidade nas ruas, a fim de propor cenários - alternativos - de Ruas Completas, tomando como objeto de estudo o bairro Centro.

O bairro Centro está situado no setor norte do município de João Pessoa e limita-se ao norte com os bairros Roger e Tambiá, ao sul com os bairros Trincheiras e Jaguaribe, a oeste com o bairro Varadouro e a leste com o bairro Torre, totalizando em uma área de aproximadamente 227 ha (Figura 2).

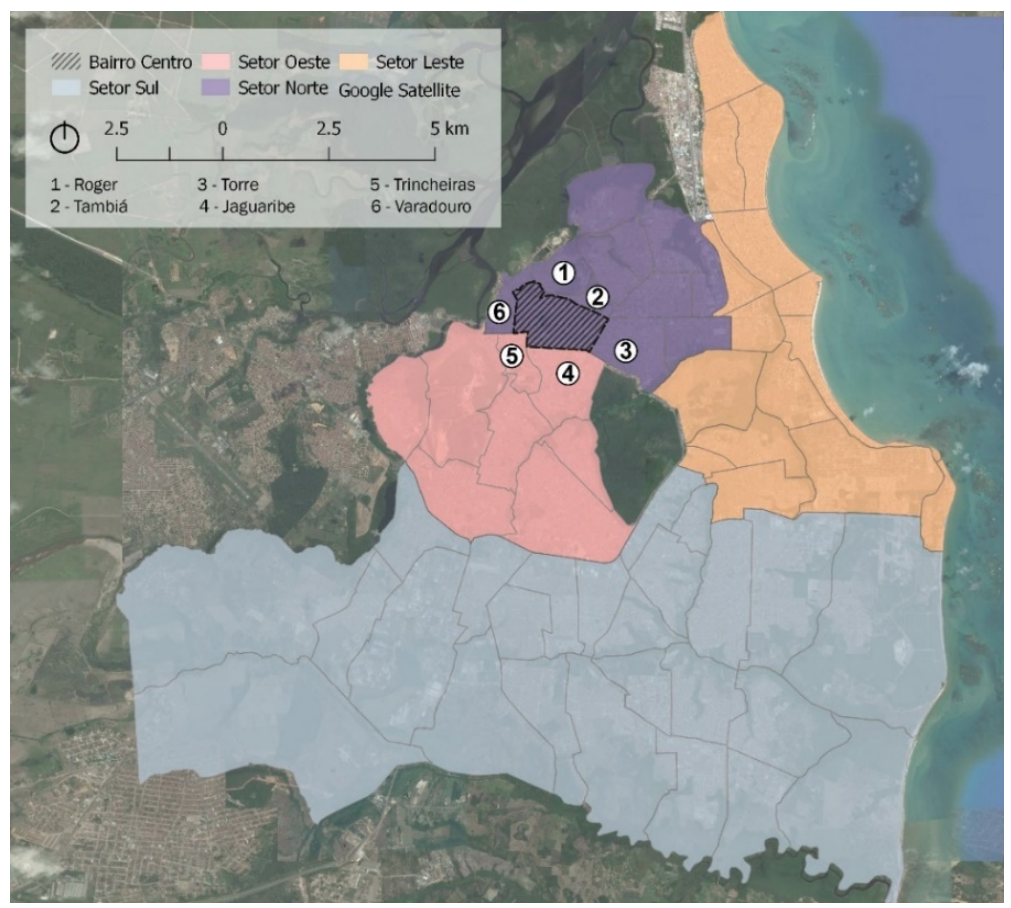

Figura 2 - Mapa de João Pessoa e localização do bairro Centro. Fonte: Adaptada pelos autores de João Pessoa (2009).

\section{Ruas completas}

Como já mencionado, o processo acelerado de urbanização tendeu a induzir o surgimento de malhas urbanas expandidas em demasia, que influenciaram diretamente a sua mobilidade, demandando melhores infraestruturas tanto para o transporte coletivo quanto o individual e dificultando o incentivo de práticas como ciclismo ou caminhada (Villaça, 2001). Como consequência, surgem inquietações da população em relação aos seus direitos sobre a cidade. Foi assim que, em 2003, surgiu nos Estados Unidos o conceito de Ruas Completas (do inglês Complete Streets), a partir de uma iniciativa do órgão "America Bikes", que propôs melhorias para inclusão das bicicletas na infraestrutura viária. 0 termo surgiu da sugestão da jornalista Barbara McCann em substituir a expressão "Routine Accommodation" - então 
usada pelo órgão para expressar a ideia de incluir bicicletas no planejamento urbano -, por uma expressão mais objetiva que ajudasse a disseminar a ideia - no caso, Ruas Completas.

Ao longo de vários encontros e com participação ativa de vários grupos, incluindo a American Planning Association (Associação Americana de Planejamento), a American Public Transportation Association (Associação Americana de Transportes Públicos), a American Society of Landscape Architect (Associação Americana de Arquitetos Paisagistas), entre outros, fez-se uma reunião para definir as diretrizes de Ruas Completas. Assim, surgiu, em 2005, a National Complete Streets Coalition (Coalizão Nacional de Ruas Completas), cujos membros fundadores incluíram a American Planning Association, bem como a Smart Growth America e outros, que promovem o desenvolvimento e a implementação de políticas de Ruas Completas. Neste contexto, Zavestoski \& Agyeman (2015) apontam que a rua é retomada em suas funções gerais, não apenas sendo utilizada como espaço livre de circulação, mas também como espaço de vivência - reuniões, negócios, lazer etc.

Segundo a WRI Cidades (2017, p. 01) - World Resources Institute -, órgão disseminador do conceito no Brasil, Ruas Completas são aquelas "[...] desenhadas para dar segurança e conforto a uma diversidade de pessoas, de todas as idades, e usuárias de todos os modos de transporte", tendo como base a distribuição do espaço de maneira mais democrática. Não existe solução única para as Ruas Completas não sendo, portanto, uma solução universal. As alternativas de desenho urbano que dialoguem com os modos de transportes ativos podem ser incorporadas, desde que adequadas ao contexto local da área. No caso deste trabalho, por se tratar de uma região central, os principais objetivos das Ruas Completas se alinham aos apresentados pela WRI Cidades (2017), conforme apresentado na Figura 3.

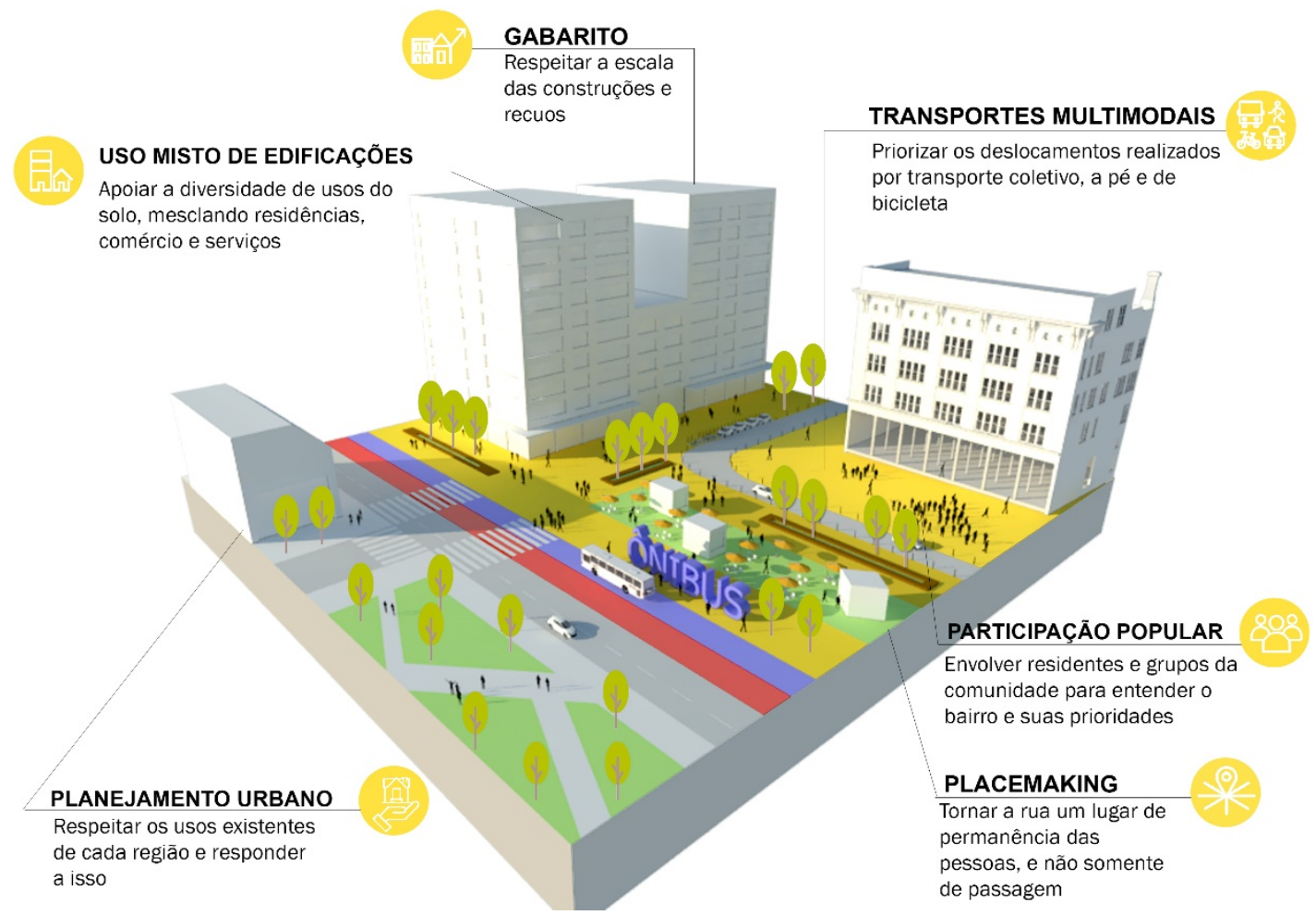

Figura 3 - Principais objetivos das Ruas Completas em regiões centrais. Fonte: Elaborada pelos autores a partir de WRI Cidades (2017).

O conceito de Ruas Completas não se relaciona com a exclusão dos veículos motorizados do cenário urbano, mas busca fomentar que o espaço público seja usado de forma democrática, priorizando os modos de transportes sustentáveis e incentivando os hábitos saudáveis como a prática da caminhada e do ciclismo. Por isso, para se implantar uma Rua Completa, é preciso haver equilíbrio nas necessidades dos usuários, 
enfatizando os elementos de maior prioridade, “[...] pois muitas vezes a largura da rua é insuficiente para acomodar faixas dedicadas ao tráfego de cada um dos usuários" (WRI Cidades, 2017, p. 01).

Existem muitos benefícios ao se adotar as Ruas Completas; não somente benfeitorias na mobilidade urbana, mas também no estímulo à economia e revitalização das cidades. Estimular o uso de edificações mistas e manter as fachadas ativas é importante para incentivar a vitalidade urbana. Para tanto, é necessário desenvolver uma política no padrão de desenho dos espaços livres públicos viários, pois estes auxiliam no planejamento urbano, sugerindo que o desenho urbano ofereça avenidas seguras e confortáveis para todos os usuários.

\section{Elementos e soluções que compõem as ruas completas, segundo WRI Brasil (2017)}

Na implantação de Ruas Completas, alguns elementos podem ser utilizados (Figura 4) como nivelamento das pistas de rolamento com as calçadas; medidas moderadoras de tráfego; acessibilidade universal; sinalização clara e orientada ao pedestre; mobiliário urbano (lixeiras, bancos, postes de iluminação etc.); faixas de segurança, estreitamento das travessias e ilhas de refúgio para pedestres; diminuição da oferta de estacionamento gratuito para carros; ciclovias e/ou ciclofaixas; faixas exclusivas de ônibus; acesso facilitado aos pontos de parada do transporte coletivo; entre outros.

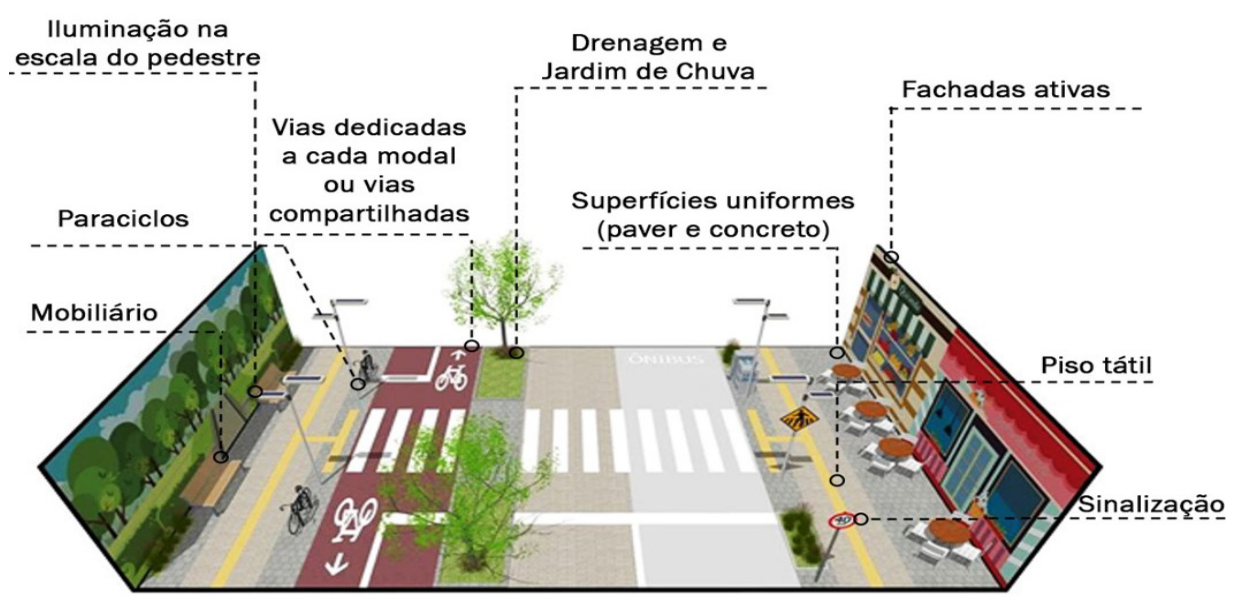

Figura 4 - Esquema de uma Rua Completa. Fonte: WRI Brasil (2017).

É importante mudar os conceitos de desenhos viários em prática no Brasil, fundamentado na priorização do trânsito e fluidez para veículos motorizados privados, negligenciando os modos de transportes não motorizados e ativos. Assim, a ideia de Ruas Completas é disseminar o conceito dos modos de transportes alternativos, de forma a influenciar o poder público a rever os processos de planejamento viário das cidades (WRI Cidades, 2017).

\section{O centro de João Pessoa}

Ao longo dos 433 anos de fundação, João Pessoa enfrentou um processo de expansão no qual houve significativas mudanças na configuração de seus espaços, principalmente na sua área central. Essas mudanças surgiram de forma mais efetiva nos anos 1930, quando a classe de maior poder aquisitivo se deslocou para as áreas de orla. Dessa forma, o processo de modernização da cidade foi direcionado à estruturação e adequação do sistema viário (Guedes, et al., 2013), que passou a percorrer caminhos mais longos entre as zonas residenciais e as de comércio e serviços.

A separação das zonas residenciais e comerciais gerou um impacto na influência econômica do Centro em relação às demais áreas da cidade, pois, em paralelo, surgiu o que Andrade et al. (2009) apontam 
como subcentros, aglomerações de comércios e serviços em outras zonas afastadas do centro, de forma a aproximar o acesso dos moradores a essas atividades.

Atualmente, admite-se que o centro urbano não necessariamente corresponde ou circunscreve-se à centralidade geográfica de uma determinada área. [...] A conjuntura contemporânea e o processo de expansão urbana possibilitaram o surgimento de aglomerações de comércio e de serviços, mais conhecidas como subcentros ou centros secundários, em novas áreas da cidade (Andrade et al., 2009).

Nas últimas décadas do século XX, as ações do Banco Nacional de Habitação (BNH) e as novas políticas habitacionais influenciaram a construção de áreas residenciais das classes menos favorecidas, cada vez mais afastadas do centro (Scocuglia, 1999; Negrão \& Silveira, 2016). Assim, surgiram gradativamente novas centralidades dentro da urbe, espalhadas entre os bairros litorâneos e a zona sul (Andrade et al., 2009). Dessa forma, foi reduzindo o caráter residencial da área central, dando espaço para vários lotes abandonados ou subutilizados e ocupações de caráter comercial ou de serviços, que causam, no período noturno, uma diminuição considerável da movimentação, quando comparada à agitação durante o dia.

A área central enfrenta graves problemas ocasionados pelas precárias condições de mobilidade do local. A infraestrutura oferecida no espaço não atende à intensidade de veículos e pessoas circulando ao longo do seu tecido urbano. Conforme a Superintendência de Mobilidade Urbana (SEMOB/JP apud Brito, 2012), o bairro Centro foi, em 2011, o líder nas estatísticas de acidentes sem vítimas e, ainda, segundo dados da Secretaria de Segurança e Defesa Social do Estado da Paraíba (2011 apud Brito, 2012), o local que apresentou maior índice de criminalidade patrimonial de João Pessoa. Essas informações podem ser justificadas tanto pelo gradativo abandono da área como também pelo modelo de planejamento do trânsito, ainda voltado para os automóveis, o que pode inibir a frequência de pedestres no espaço público.

Porém, apesar de toda essa problemática, a área central da cidade não perdeu sua importância quanto à centralidade urbana; pelo contrário, permanece ainda com uma forte polarização e relação com o resto da cidade, sendo ainda um importante polo da economia local (Andrade et al., 2009).

\section{Caracterização e diagnóstico do bairro Centro}

Por muitos anos, o Centro foi um local importante para as moradias e para o trabalho das classes da elite, pois era onde se situavam os principais edifícios públicos, administrativos e religiosos. Porém, com o esvaziamento das moradias ao longo do tempo, esse bairro configura-se, atualmente, como uma área de grande concentração de comércio e serviços. Também é um local de variadas atividades culturais, como shows, festas tradicionais e manifestações políticas, mantendo a dinâmica e movimentação de pessoas nos finais de semana.

De acordo com o Plano Diretor em vigor (João Pessoa, 1992), o Centro se localiza na Zona de Adensamento Prioritário (ZAP), onde a disponibilidade de infraestrutura básica e de rede viária e o meio ambiente permitem a intensificação do uso e ocupação do solo, e onde o índice de aproveitamento único poderá ser ultrapassado até o limite de 4,0, conforme o instrumento outorga onerosa previsto na Lei Federal no 10.257.

\section{Perfil socioeconômico}

\section{Densidade e renda}

Segundo os dados do IBGE (2010), a cidade de João Pessoa apresenta uma densidade demográfica de 33,7 hab/ha, enquanto no Centro da cidade a densidade populacional é de 15,9 hab/ha, o que, segundo Zmitrowicz \& De Angelis (1997), é uma densidade bem abaixo da média dos centros urbanos das cidades brasileiras. Já a densidade habitacional líquida de João Pessoa é de 31 habitações/ha, e no Centro, de 28,8 habitações/ha (Silva et al., 2016, p. 12). 
Para Zmitrowicz \& De Angelis Neto, a densidade média de 60 famílias por hectare (cerca de 200 hab./ha) é confortável para os centros urbanos, mas os autores afirmam que a média global da maioria das cidades brasileiras é de 15 famílias por hectare (cerca de 50 hab./ha).

De acordo com os dados do censo do IBGE, entre 2000 e 2010 a população de João Pessoa cresceu 17,3\%, passando de 597.934 para 723.515 habitantes. Entretanto, na área de estudo, houve um decréscimo acentuado de $27 \%$ de sua população, totalizando 3.644 habitantes em 2010 , o que significa que apenas $0,5 \%$ da população da cidade reside no Centro. Nesse mesmo período, o número de domicílios aumentou apenas 7,6\% no bairro analisado, passando de 1.418 para 1.535 domicílios.

Os dados do censo do IBGE de 2000 indicam que a renda média da área de estudo era de $\mathrm{R} \$ 1.380,00$, em torno de 9 salários mínimos (R\$ 151,00) à época. A variação entre o menor e o maior salário estava entre 0 e 10 salários mínimos, identificando um perfil de classe média. Já em 2010, essa média subiu para $\mathrm{R} \$ 2.869,04$, porém esse valor corresponde a apenas 5,6 salários mínimos. Esse fato se relaciona com o deslocamento de parte da população para outras áreas da cidade, a partir do seu processo acelerado de urbanização e expansão, iniciado em meados do século XX.

A falta de pessoas residentes no Centro, a pouca diversidade de classes sociais e o baixo curso de investimentos em manutenção, por parte dos gestores urbanos, influenciaram a perda de qualidade do ambiente construído e de segurança do local.

\section{Pavimentação das ruas e calçadas}

Segundo contagens realizadas in loco, pôde-se aferir que no bairro existe um número maior de avenidas asfaltadas, que somam $46 \%$ das suas vias totais, enquanto $43,5 \%$ são revestidas com paralelepípedos e apenas 10,5\%, ou 10 ruas, encontram-se totalmente pedestrianizadas. Segundo dados de 2010 do Relatório do Índice de Qualidade de Vida Urbana de João Pessoa/PB do Laboratório do Ambiente Urbano e Edificado (LAURBE) da Universidade Federal da Paraíba (UFPB), bem como visitas ao local, pôde-se perceber que $73 \%$ das calçadas dos lotes se encontram conservadas, enquanto $27 \%$ dos lotes não possuem calçadas ou estão danificadas. Durante a visita ao local (Figura 5), notou-se que, em alguns pontos, elas são estreitas ou possuem conflitos de pedestres com ambulantes, não apresentando dimensão suficiente para receber a demanda de transeuntes da área. Percebeu-se também a necessidade em adotar medidas para otimizar a acessibilidade em diferentes áreas do bairro, ainda precária e com pouca conformidade com as normas.

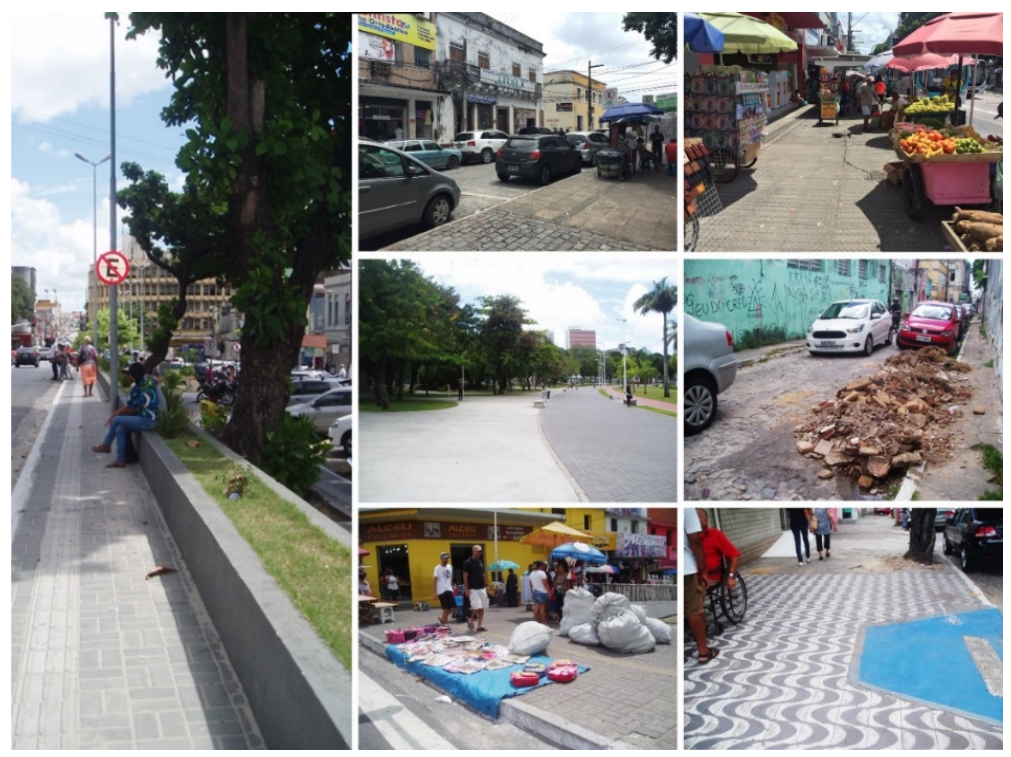

Figura 5 - Situação das calçadas ao longo do Centro de João Pessoa. Fonte: Autores (2018). 


\section{Uso do solo}

Analisando os mapas de uso e ocupação do solo (Figuras 6 e 7), pôde-se concluir quatro fatos: (1) comércios e serviços ocupam uma expressiva parte da área; (2) há um grande número de lotes vazios ou subutilizados; (3) as residências acentuam-se nos locais mais afastados da concentração de comércios e serviços; e (4) o bairro apresenta um caráter diurno, com baixa movimentação noturna, possivelmente como consequência dos fatos anteriores. Portanto, pode-se afirmar que o Centro é um bairro com predominância de comércio e serviços, com maior vitalidade durante o dia e uma grande quantidade de lotes desocupados, como já observado por Silva (2016).

Segundo Silva (2016), também existe diferença na ocupação dos imóveis quando analisados por pavimentos. "Na medida em que os andares sobem, declina-se a quantidade de comércios e serviços, e torna-se predominante a porcentagem de vazios e armazenagem, demonstrando a subutilização dos pavimentos superiores das edificações" (Silva, 2016, p. 65). Em razão dessa condição, percebeu-se a dificuldade de contato com os usuários e/ou proprietários desses imóveis, a fim de mapear o uso e ocupação destes, surgindo dúvidas quanto à existência e/ou predominância do uso misto - tendo sido aferidos casos pontuais e que, diante da dúvida, foram identificados pelo seu uso predominante.

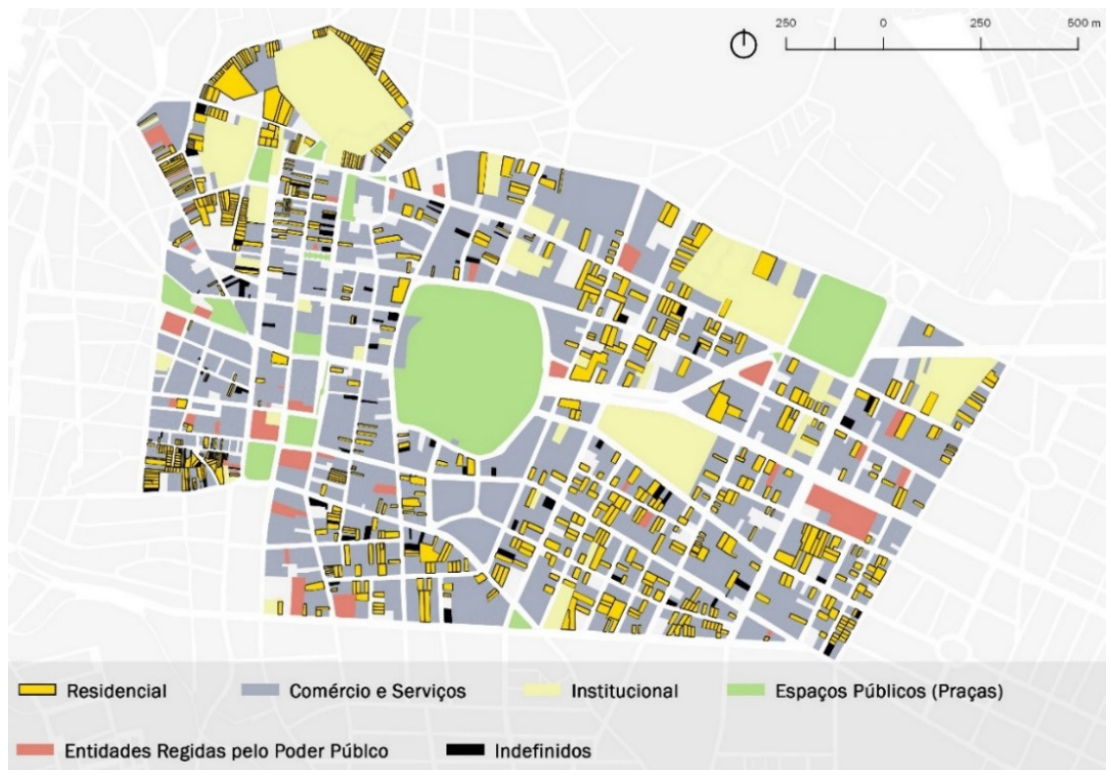

Figura 6 - Mapa de uso e ocupação do solo. Fonte: Adaptada pelos autores de UFPB (2010).

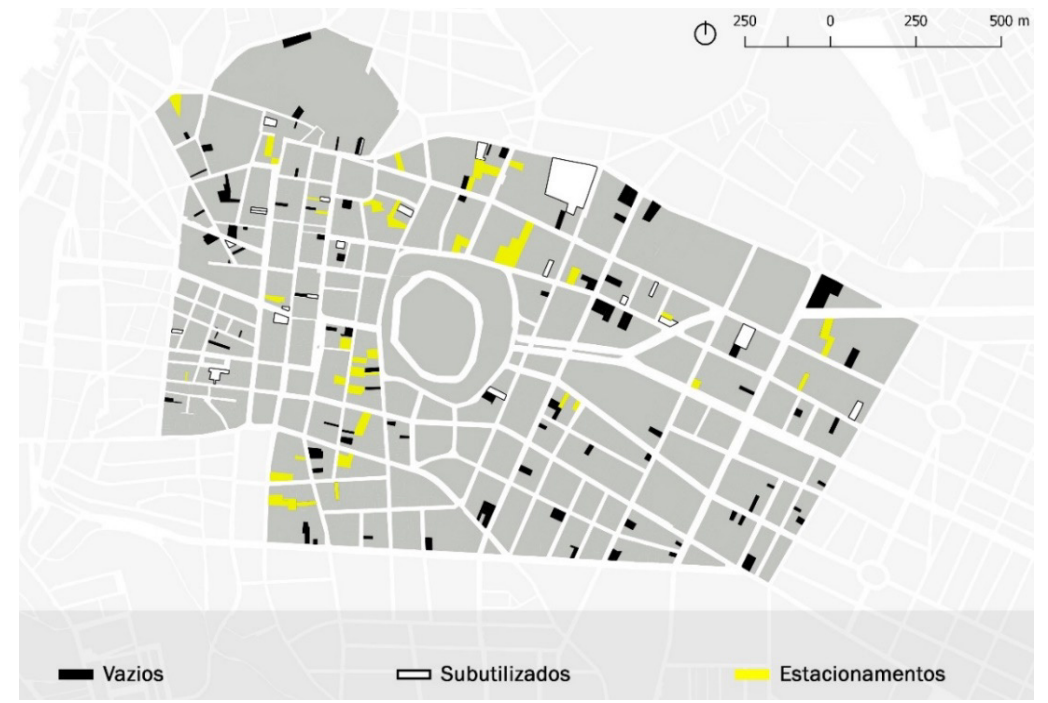

Figura 7 - Mapa de vazios urbanos. Fonte: Adaptada pelos autores de UFPB (2010). 
Entre os lotes ocupados com comércios e serviços, apenas uma parcela pequena funciona também à noite (Figura 8), como bares, pousadas, shoppings e o parque da Lagoa. Essa característica, quando somada à falta de residências no local e aos lotes vazios, caracteriza o Centro em dois cenários: o primeiro, um Centro com elevada movimentação de pessoas nos períodos da manhã e tarde; e o segundo, um Centro com grau elevado de subutilização.

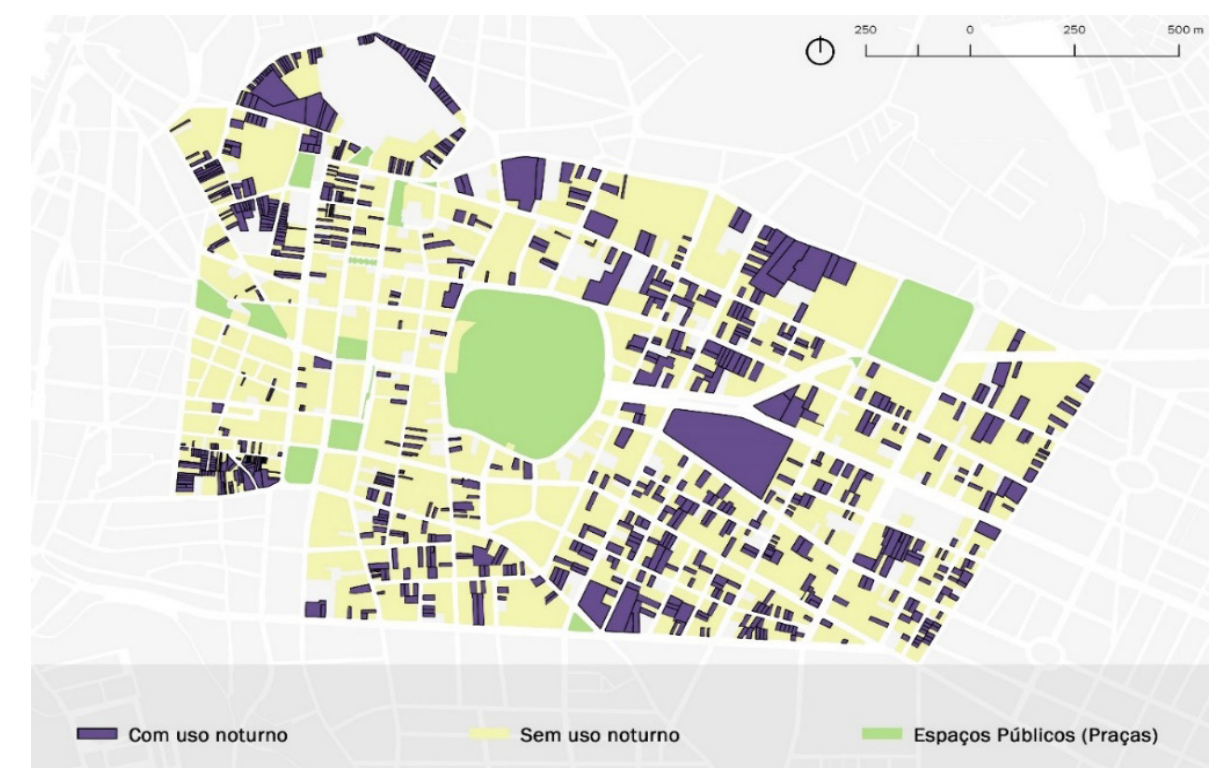

Figura 8 - Mapa de uso do solo por turno. Fonte: Adaptada pelos autores de UFPB (2010).

Sendo assim, Silva (2016, p. 70) afirma que "[...] a falta de vigilância, proporcionada pela presença de unidades de vizinhança e comércios à noite, promove a sensação de insegurança, que desmotiva o trânsito de pedestres e a vinda de novos moradores à área".

Desta forma, o bairro Centro apresenta, atualmente, uma parcela alta de lotes utilizados para comércios e serviços, com $64 \%$. A porcentagem de lotes usados para residências é menor, com $25 \%$. Os lotes vazios, subutilizados e estacionamentos referem-se a $7 \%$, um valor considerável, que totaliza 53 estacionamentos, 125 lotes vazios e 22 subutilizados.

Dos lotes ocupados, $27 \%$ (815) deles funcionam também à noite, considerando residências, comércios e serviços. Porém, entre os lotes de comércios e serviços, apenas 3\% (67) funcionam à noite, que se referem a bares, pousadas, hospitais, escolas, igrejas, postos de gasolina e farmácias. Assim, pôde-se confirmar a diferença da movimentação no Centro durante o dia e a noite, uma vez que a utilização dos edifícios chega a uma média de $95 \%$ no período diurno, enquanto, no período noturno, a estatística inverte para $28 \%$ de lotes ativos.

\section{Sistema viário e mobilidade}

O sistema viário apresenta conflitos de uso e ocupação, e fluxo ao longo do bairro - considerando as relações com o ambiente construído e seus usos do solo. Por se tratar de uma área central e bastante comercial, o Centro é o destino de muitas viagens originadas de todas as partes da cidade. Quando essas viagens são analisadas na ótica dos meios de transporte, percebe-se a predominância dos veículos motorizados particulares em detrimento dos transportes coletivos e ativos.

A confluência das viagens, com o alto número de veículos motorizados, gera um fluxo intenso de automóveis nas principais avenidas do bairro (Figura 9), que funcionam como vias conectoras do Centro com o resto da cidade. 


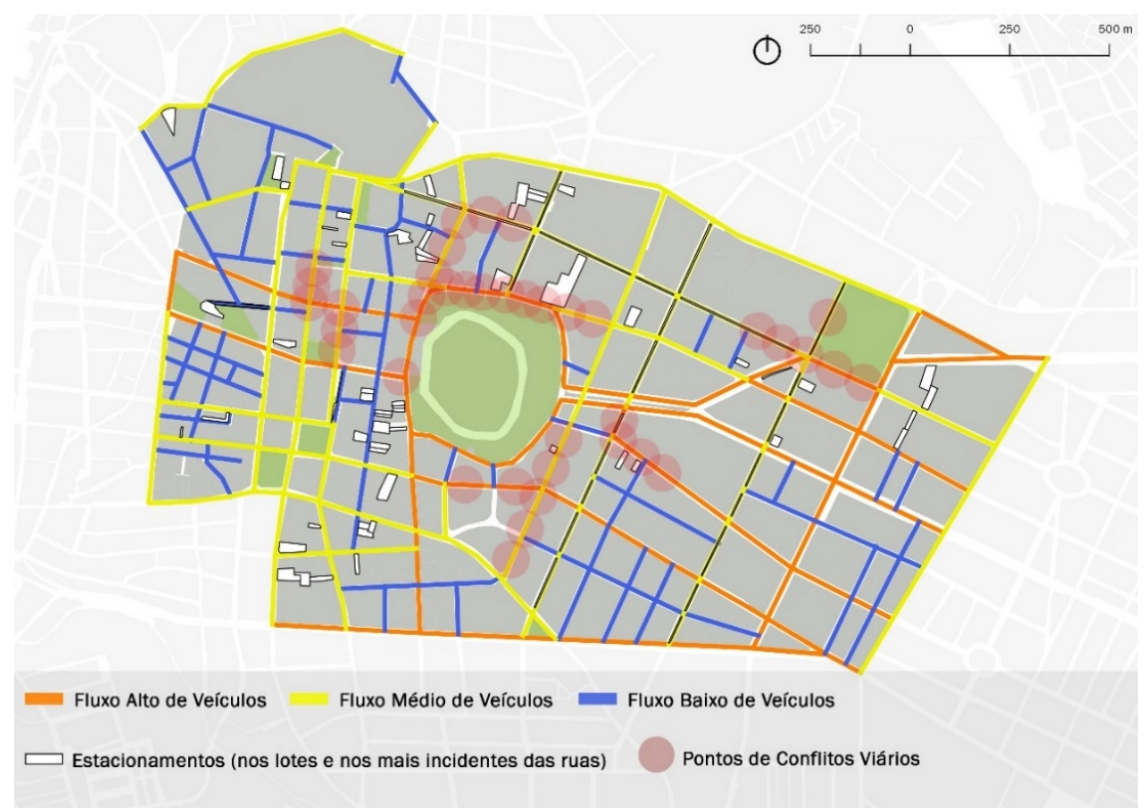

Figura 9 - Mapa do fluxo de automóveis. Fonte: Elaborada pelos autores (2018).

A instalação de empreendimentos no bairro tem um grande impacto na mobilidade da área, sendo eles que convidam pessoas a vivenciar o local. A instalação de tais empreendimentos não acompanha o planejamento urbano viário, ocasionando conflitos de atividades entre pessoas e automóveis, que precisam se locomover no mesmo espaço.

Um desses conflitos pode ser observado com o transporte público coletivo, uma vez que o bairro recebe uma grande demanda de linhas de ônibus (Figura 10), porém não tem infraestrutura urbana necessária para atender a todas elas. Segundo dados da Secretaria de Mobilidade Urbana de João Pessoa (2012), atualmente João Pessoa apresenta uma frota cadastrada de 535 ônibus, dos quais 506 circulam no Centro, ou seja, $94,5 \%$ da frota de ônibus o tem como destino/origem de viagens.

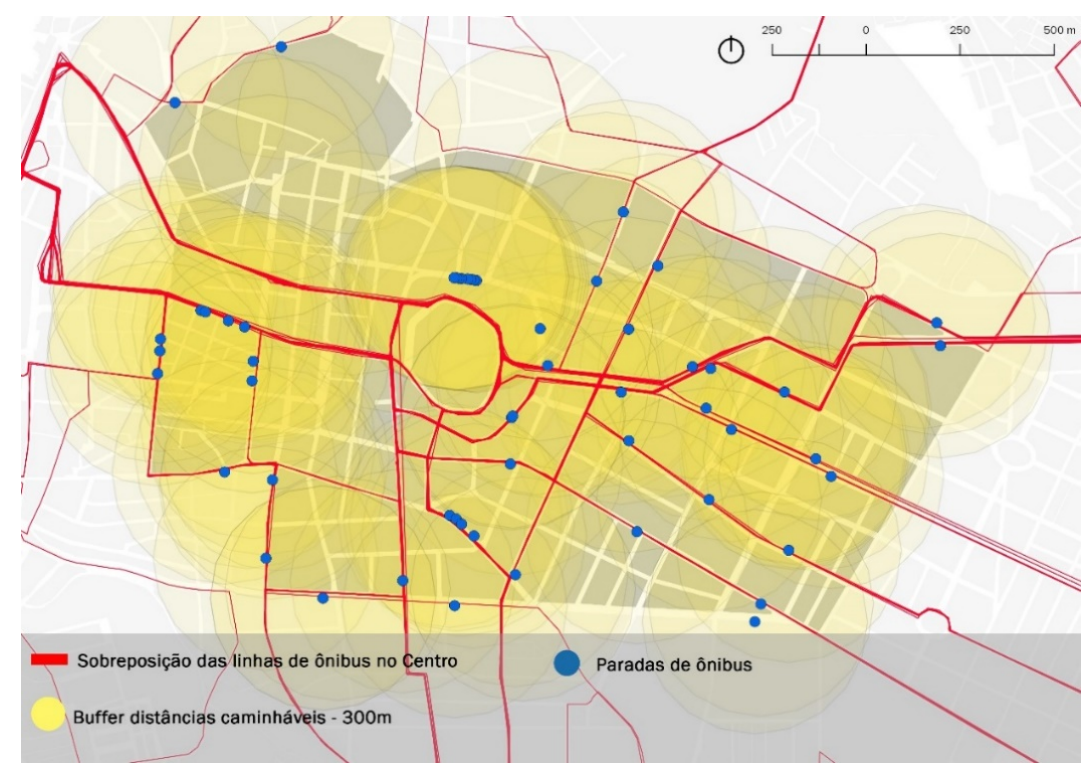

Figura 10 - Mapa de linhas de transporte coletivo. Fonte: Elaborada pelos autores (2018).

Quanto à mobilidade de ciclistas, propôs-se, em 2012, o Plano Cicloviário de João Pessoa, que, segundo a Prefeitura Municipal de João Pessoa (2014, p. 123), “[...] engloba 82,03 km de ciclovias, e que, somada ao sistema existente e proposto por secretarias do município, vai ultrapassar os $150 \mathrm{~km}$ de vias cicláveis". 
Durante visitas ao local, não se notou nenhuma infraestrutura destinada aos ciclistas, embora a topografia não seja considerada um obstáculo; apenas a ciclovia interna do parque da Lagoa, o que acarreta a pouca presença de bicicletas ao longo do espaço público viário do Centro. As exceções são representadas por moradores do entorno, que utilizam esse modo de transporte como principal.

Ao andar pelas ruas, pôde-se perceber que, mesmo existindo grande quantidade de pessoas, o bairro ainda é considerado inseguro para a caminhada dos transeuntes, já que a infraestrutura urbana para esse meio de transporte não é adequada. Assim, alguns fatos foram constatados: (1) o conforto físico e climático só é presente em algumas praças por causa da arborização; (2) na paisagem é predominante a imagem do automóvel, uma vez que parte considerável das vias funciona também como estacionamento; (3) a insegurança no período diurno pode ser causada tanto pela alta presença de veículos motorizados como pelo esvaziamento de pessoas em algumas áreas; (4) a insegurança no período noturno é causada pelo esvaziamento considerável de pessoas em quase todo o bairro; e, por fim, (5) a grande concentração de ambulantes nas calçadas dificulta a livre locomoção do caminhante.

\section{Sintaxe espacial}

As análises de integração e conectividade são utilizadas neste artigo como método comparativo, que prevê as áreas de maior potencial de movimentação de pessoas, bem como a integração e conectividade das ruas no Centro. Assim, utilizou-se da movimentação de pedestres pelo bairro como critério de análise, mapeando percursos formais e informais realizados por eles.

O mapa axial de integração (Figura 11) teve como resultados ruas com integração de no máximo 1,911 e no mínimo 0,5. Conforme apontado por Hillier \& Hanson (1984), linhas axiais com valores de integração superior a 1,67 podem ser consideradas altamente integradas. As ruas mais integradas são, respectivamente, a rua Duque de Caxias $(1,911)$, rua Mal. Almeida Barreto $(1,883)$, avenida João Machado $(1,870)$, avenida Visconde de Pelotas $(1,860)$ e avenida Pedro I $(1,827)$, que possuem intenso fluxo de comércio, serviços e pessoas; e as menos integradas são ruas locais, em que há a presença de apenas residências ou lotes vazios, como o caso do Beco dos Milagres, da Ladeira de São Francisco, da rua Travessa e rua Índio Piragibe.

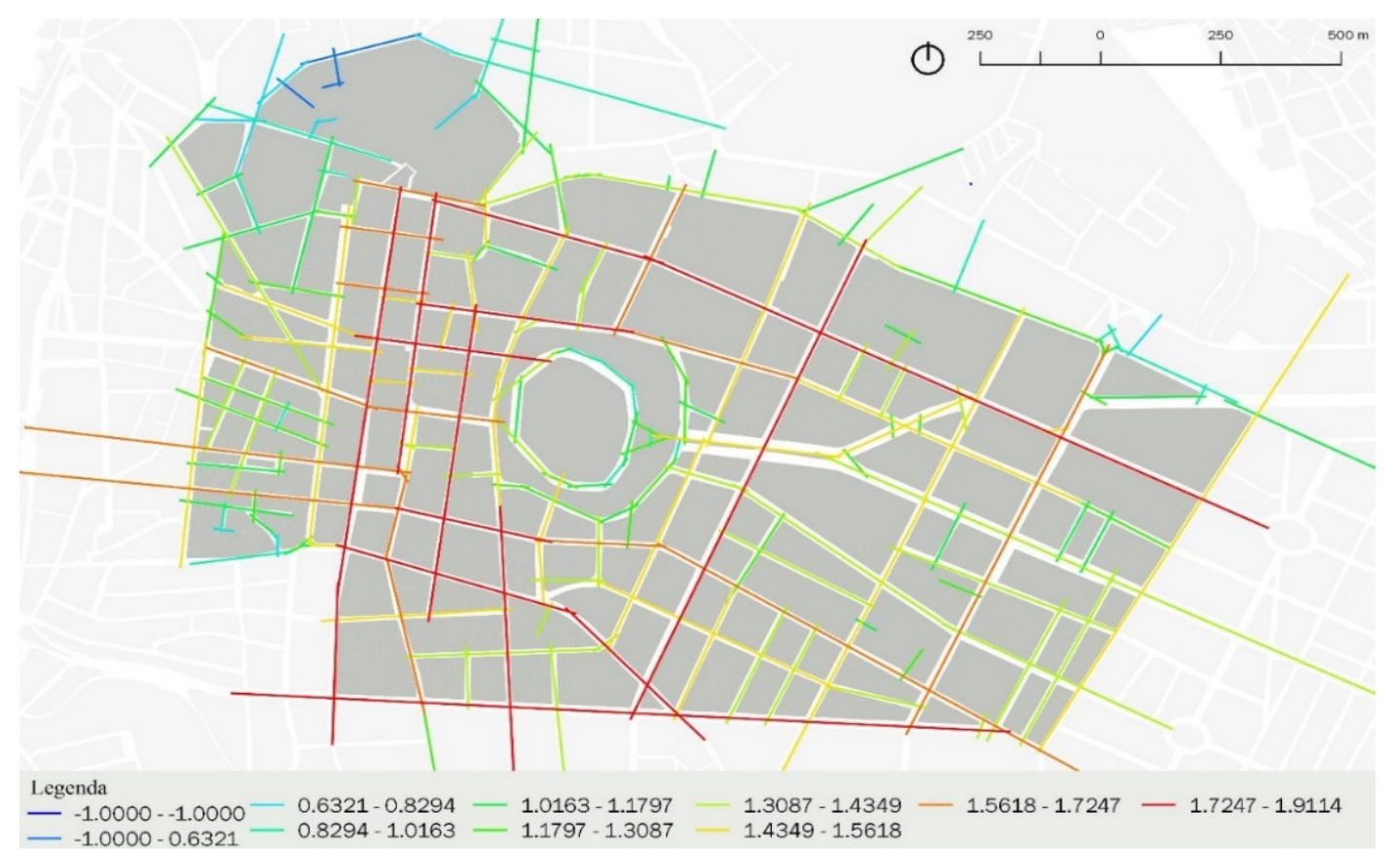

Figura 11 - Mapa axial de integração. Fonte: Elaborada pelos autores (2018). 
As linhas de conectividade do bairro (Figura 12) variam entre 1 e 15 conexões - lembrando que a análise sintática foi feita na escala do bairro, e não da cidade. Os resultados demonstram que as avenidas mais conectadas do Centro são: a avenida João Machado (15 conexões), a avenida Visconde de Pelotas (14), as avenidas General Osório e Dom Pedro I (13) e a rua Duque de Caxias (12), que confirmam o conceito de conectividade, uma vez que são ruas de grande importância na movimentação dessa área.

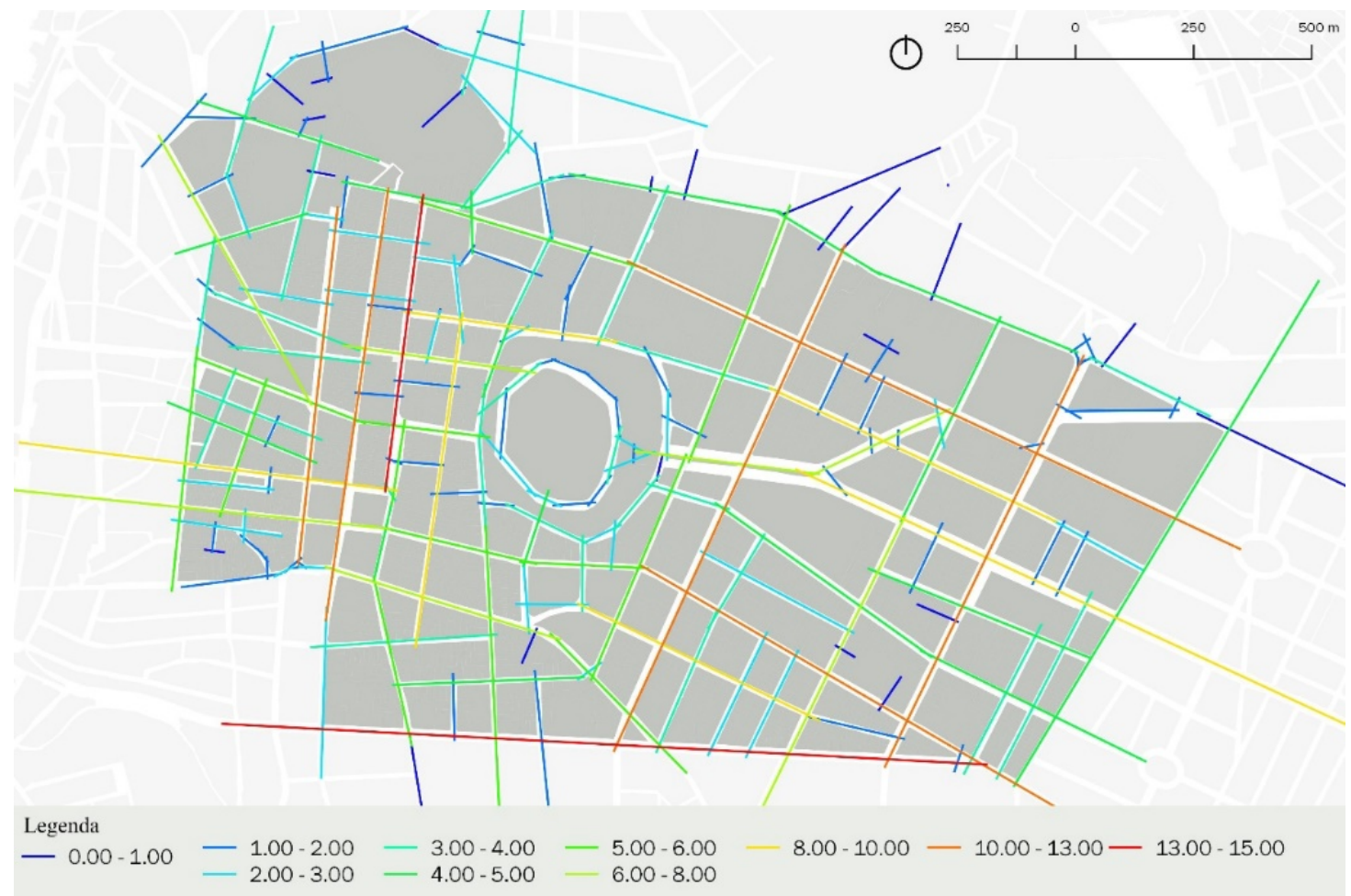

Figura 12 - Mapa axial de conectividade. Fonte: Elaborada pelos autores (2019).

A análise sintática não considera variáveis temporais, porém, pelo fato de o bairro Centro ter uma movimentação predominantemente diurna, tomou-se como referência esse período para mapear a movimentação dos pedestres. Desta forma, a análise auxiliou na comprovação de quais são as avenidas que se destacam no traçado do bairro, possibilitando a previsão dos fluxos de pedestres.

\section{Delimitação do objeto de intervenção}

Para a delimitação dos objetos de intervenção no bairro, necessitou-se estabelecer critérios de análise visando ao conceito de Ruas Completas, para, então, analisar quais os locais que precisavam, prioritariamente, receber uma instalação dessa natureza.

Analisando o conceito de Ruas Completas, notou-se que a principal diretriz é inverter a pirâmide existente, em que o automóvel particular domina o topo em detrimento dos modos ativos (ciclistas e pedestres), e algumas formas de promover isso é manter a circulação desses modos ativos de forma segura e confortável por meio de: fachadas ativas, usos mistos, que garantem a movimentação de pessoas durante todos os horários do dia, e infraestrutura adequada aos pedestres e ciclistas.

Dessa forma, analisou-se o diagnóstico produzido, tendo como critérios de escolha (Tabela 1):

1. As ruas que apresentam maior integração;

2. As ruas que apresentam maior conectividade;

3. As ruas que apresentam maior concentração de pessoas; 
4. As ruas que apresentam conflitos entre os modais;

5. As ruas que apresentam um menor número de residências;

6. As ruas que apresentam um menor número de lotes com uso noturno.

Ainda, para a definição dessas avenidas, consideraram-se também as suas localizações no bairro, de forma que possam contribuir como uma rede funcional, que determina os principais passeios e destinos dos pedestres ao longo do local. A proximidade das avenidas pode ofertar um percurso suave e interessante para o passeio dos visitantes, incentivando que as mesmas medidas sejam tomadas para o entorno imediato.

Tabela 1 - Critérios de escolha das áreas de intervenção

\begin{tabular}{|c|c|c|c|c|c|c|c|}
\hline & 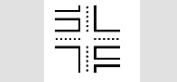 & * & هْهిْ & 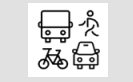 & 略合 & 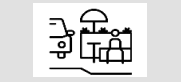 & \\
\hline Ruas & Integração & Conectividade & Pessoas & Conflitos & Residências & Uso noturno & Total \\
\hline $\begin{array}{l}\text { R. Duque de } \\
\text { Caxias }\end{array}$ & $\checkmark$ & 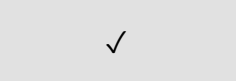 & $\checkmark$ & $\checkmark$ & $\checkmark$ & $\checkmark$ & 6 \\
\hline R. Santo Elias & & & $\checkmark$ & $\checkmark$ & $\checkmark$ & $\checkmark$ & 4 \\
\hline $\begin{array}{l}\text { Av. Miguel } \\
\text { Couto }\end{array}$ & & & $\checkmark$ & $\checkmark$ & $\checkmark$ & $\checkmark$ & 4 \\
\hline $\begin{array}{l}\text { R. Eliseu } \\
\text { Cesar }\end{array}$ & $\checkmark$ & & & & $\checkmark$ & $\checkmark$ & 3 \\
\hline $\begin{array}{l}\text { R. Almirante } \\
\text { Barroso }\end{array}$ & & & $\checkmark$ & $\checkmark$ & & & 2 \\
\hline $\begin{array}{l}\text { Av. João } \\
\text { Machado }\end{array}$ & $\checkmark$ & $\checkmark$ & & & & & 2 \\
\hline $\begin{array}{l}\text { Av. Guedes } \\
\text { Pereira }\end{array}$ & & & $\checkmark$ & & $\checkmark$ & $\checkmark$ & 3 \\
\hline $\begin{array}{l}\text { Av. Almeida } \\
\text { Barreto }\end{array}$ & $\checkmark$ & & & & & & 1 \\
\hline Av. Pedrol & $\checkmark$ & $\checkmark$ & & $\checkmark$ & & & 3 \\
\hline $\begin{array}{l}\text { Av. General } \\
\text { Osório }\end{array}$ & & $\checkmark$ & & & & & 1 \\
\hline
\end{tabular}

Fonte: Elaborada pelos autores (2019).

Para este trabalho, selecionaram-se as duas avenidas de maior pontuação (Figura 13). Embora existam avenidas com a mesma pontuação, o critério de desempate para escolha foi aquele em que se notou a maior urgência de intervenção nas análises comportamentais - relação entre pessoas e espaço público, como integração e conectividade. 


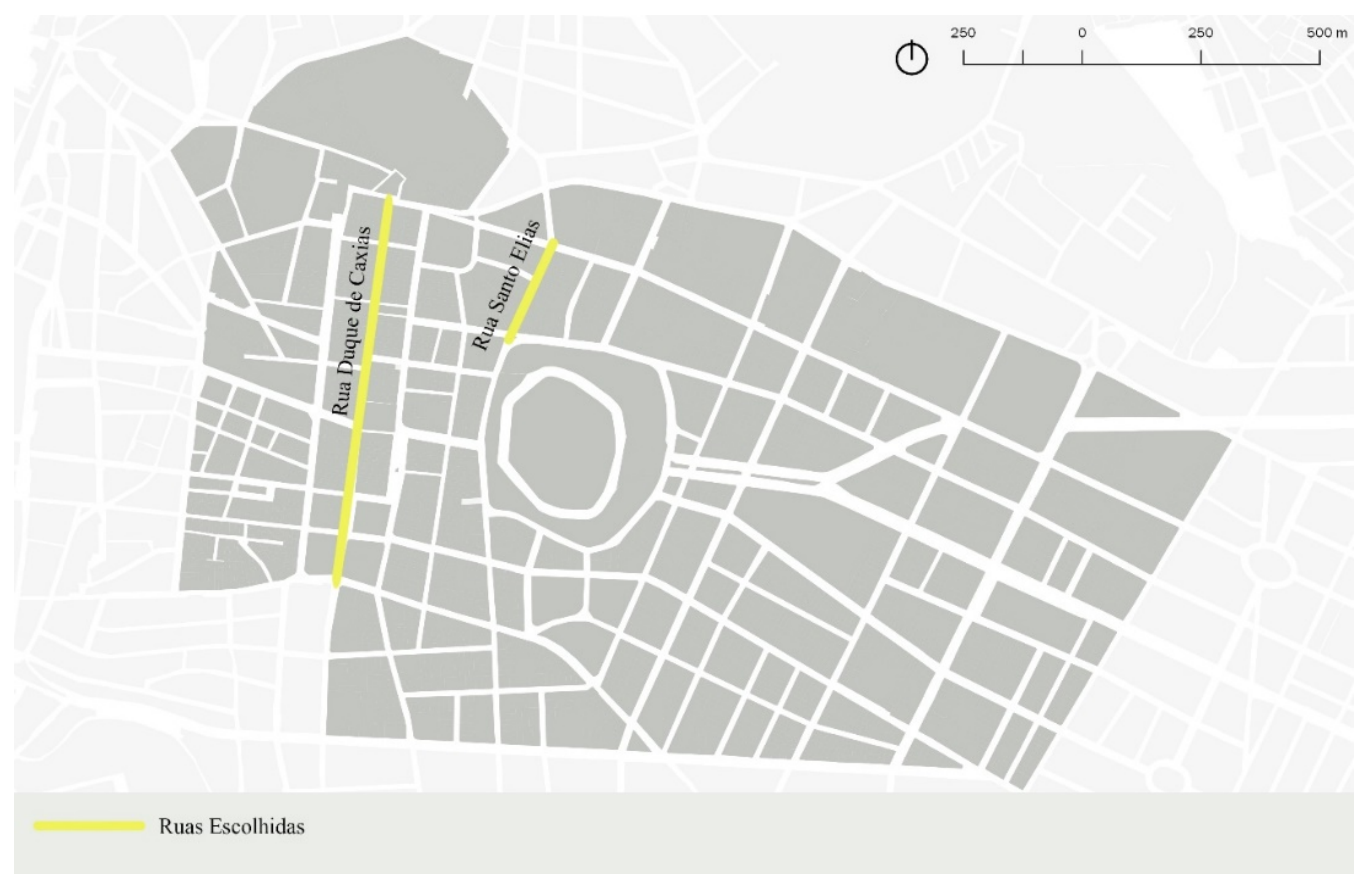

Figura 13 - Mapa de localização das avenidas selecionadas. Fonte: Elaborada pelos autores (2018).

\section{Análise das áreas selecionadas}

Uma vez selecionadas, realizou-se a análise comportamental das áreas escolhidas, em que se utilizou da metodologia criada por Gehl \& Svarre (2013). Fez-se uso, então, dos métodos counting, mapping, photographing, keeping a diary (contando, mapeando, fotografando e mantendo um diário), que se compatibilizaram no escopo do trabalho e que auxiliaram no levantamento mais preciso dos fluxos e comportamentos da população do bairro.

O método counting é um dos mais utilizados, e, por meio dele, pode-se registrar quantas pessoas estão caminhando (fluxo de pedestres) e quantas pessoas permanecem em determinados locais. Segundo o autor, é importante conduzir a contagem por exatamente 10 minutos, pois essa é uma amostra aleatória que, mais adiante, terá de ser repetida para calcular o tráfego de pedestres por hora; o mapping, ou mapa comportamental, é uma forma de registrar o que acontece em determinado local, como indicar onde as pessoas permanecem e que tipo de atividade está sendo feita; o photographing auxilia na ilustração dos comportamentos e também para informações complementares ao mapeamento; o keeping a diary é uma maneira de adicionar minúcias aos mapeamentos - anotar detalhes e nuances podem aumentar o conhecimento sobre o comportamento humano no espaço público.

Por se tratar de uma área ampla, não foi viável a realização desses métodos em toda a extensão das ruas, pois necessitaria de um grupo de pessoas dispostas ao longo das avenidas. Dessa forma, optou-se por utilizar como auxílio o método do portal apresentado por Vaughan (2001). 0 método consiste na implantação de portais em locais específicos do bairro. Esses portais são linhas imaginárias posicionadas em frente ao espaço analisado pelo pesquisador, que irá fazer a contagem de pessoas - ou qualquer modal - que atravessam essa linha, em um intervalo predeterminado de tempo.

A sugestão de Vaughan (2001) é que esses portais sejam espalhados em áreas com características distintas, que possuam alto, médio e baixo fluxo para uma avaliação mais completa da área de estudo. Também se recomenda que, em áreas de grande movimentação, as medições durem 2,5 minutos em cada portal, porém, uma vez que a recomendação de Gehl \& Svarre (2013) é de 10 minutos para cada contagem, optou-se por seguir esse tempo para evitar uma contagem muito superficial.

Desta forma, selecionaram-se os locais para posicionamento dos portais (Figura 14) e estabeleceu-se um ciclo de observação, conforme análise prévia das atividades desenvolvidas no Centro - das $9 \mathrm{~h}$ às $12 \mathrm{~h}$, das $14 \mathrm{~h}$ às 
16h30 e das $19 \mathrm{~h}$ às $20 \mathrm{~h}$. Fez-se a escolha por dias típicos - segunda, quarta e sexta -, nos horários de alto e baixo pico do bairro. Por causa do grande esvaziamento da área no período da noite, não se fez a observação do horário das $19 \mathrm{~h}$ às $20 \mathrm{~h}$ em alguns portais, pois tornaria o procedimento inseguro.

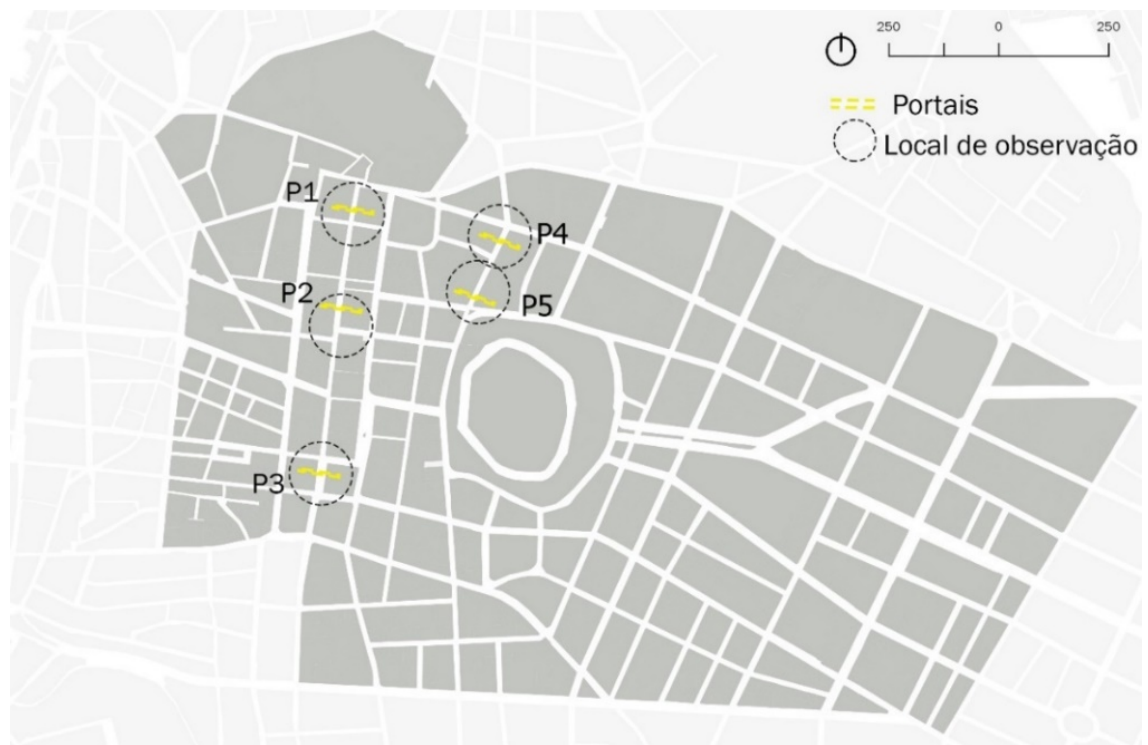

Figura 14 - Localização dos portais ao longo do Centro. Fonte: Elaborada pelos autores (2018).

\section{Resultados}

Os ensaios aqui propostos seguem as diretrizes utilizadas pelo conceito de Ruas Completas. Desta forma, propôs-se que as avenidas selecionadas possam promover uma distribuição do espaço mais igualitária entre os modos de transporte, por meio da ampliação das calçadas para os pedestres e implantação de ciclovias, na busca por priorizar as modalidades sustentáveis. Outro ponto-chave foi oferecer espaços atrativos para a permanência de pessoas ao longo das avenidas, incentivando uma crescente vitalidade ao bairro; assim, propôs-se a inserção de mobiliário adequado e acessível, arborização e espaços de convivência e realização de eventos.

Buscou-se intervir nos pontos de conflitos encontrados, em que um dos principais é a ausência de locais para estacionamento de automóveis. Embora a proposta tivesse o intuito de reduzir o acesso de veículos particulares, ela também incentivou a democratização do espaço público. Desta maneira, para atender à grande demanda de pedestres nas vias, necessitou-se pensar em formas de ampliar os espaços para eles e também garantir a movimentação, independentemente da escolha do meio de locomoção. Portanto, decidiu-se que nas avenidas mais largas, com possibilidade de comportar todos os modos de transportes, sejam implantados estacionamentos em um de seus lados - separados por espaços de permanência para pedestres -, não criando barreira que impeça a boa visibilidade. É interessante que esses estacionamentos sejam também destinados para as necessidades especiais, deficientes e idosos, bem como para carga e descarga, que acontece com frequência nas vias estudadas.

Para atender ao outro montante da demanda, propôs-se que os lotes vazios encontrados nas bordas do bairro sejam ocupados com edifícios de uso misto (Figura 15), de porte médio - até 6 pavimentos -, e que eles disponham obrigatoriamente de fachadas ativas no térreo, estando os estacionamentos situados no subsolo. Desta forma, pode-se aproveitar um solo que já oferta infraestrutura adequada e incentiva o uso de edificações mistas e fachadas ativas; quando necessário, é possível o uso do instrumento outorga onerosa - pertencente a Lei Federal no 10.257 -, por causa do fato de a área objeto de estudo estar presente na zona de adensamento prioritário, conforme indicado no Decreto N. 6.499 (João Pessoa, 2009). 


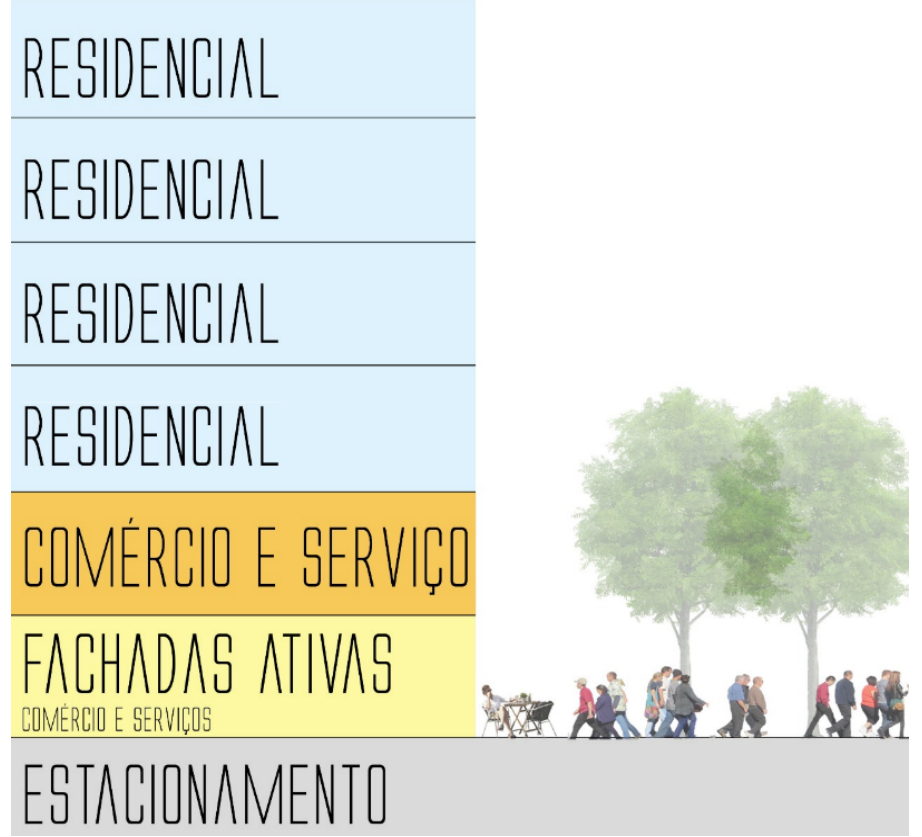

Figura 15 - Esquema dos edifícios propostos para implantação de estacionamentos. Fonte: Elaborada pelos autores (2019).

O segundo conflito encontrado foi a presença de ambulantes dispostos nas calçadas, ocupando e diminuindo a faixa livre de caminhada dos pedestres. Durante as observações in loco, pôde-se notar que os ambulantes são responsáveis por manter uma dinâmica de fluxos interessante no bairro. Dessa forma, não se indicou a retirada deles do espaço público viário, mas sim a organização por meio de uma demarcação no piso que delimita o espaço que pode ser ocupado, chamado aqui de Faixa Amarela, no qual as barracas serão uniformizadas e distribuídas à posse dos ambulantes que já estão consolidados na área, além de oferecer locais para permanência de ambulantes móveis. Essa tomada de decisão foi considerada viável, pois não se aferiram conflitos entre os ambulantes e os comerciantes dos estabelecimentos locais, apenas problemas relacionados à mobilidade e à acessibilidade nas calçadas.

Outro fator importante foi determinar a implantação de fachadas ativas que permaneçam em funcionamento durante todos os horários do dia, pois a relação das áreas privadas com as públicas influencia a vitalidade do espaço urbano. Notou-se que, ao longo das avenidas estudadas, a maioria das edificações já dispõe de fachadas ativas, uma vez que a testada dos lotes é voltada para as ruas e possui janelas, portas e vitrines, sendo que nem todas se comportam de forma convidativa. Outra questão é que as fachadas ativas são ocupadas apenas por comércio e serviços que só funcionam em horário comercial - das $8 \mathrm{~h}$ às 18h; poucas são ocupadas por bares, restaurantes e atividades culturais, que possibilitam o movimento no período noturno.

Desta forma, para a implantação de fachadas ativas nos lotes que ainda não a possuem, utilizou-se como correlato do "Plano Diretor Estratégico do Município de São Paulo" (São Paulo, 2014), estabelecendo que lotes com mais de 20 metros de testada sejam destinados a usos não residenciais no térreo, oferecendo o incentivo de que "[...] não serão computáveis, até o limite de $50 \%$, a área do lote destinada à implementação deste instrumento". Para os lotes que se encontram vazios ou subutilizados, deve-se continuar a aplicação do IPTU progressivo no tempo, em que "[...] o poder público notifica os proprietários para que, no prazo de um ano, apresentem projeto de edificação no terreno, ou ainda de ocupação da construção, quando esta já existe" (São Paulo, 2014, p. 67). É importante também que se incentive a inserção de atividades culturais e comércios noturnos nos lotes, por meio de programas do governo, como o Anima Centro, programa que promove espetáculos, shows e exposições no bairro.

Para a representação das decisões das fachadas ativas do estudo, elaborou-se uma escala de cores, representando a ação necessária para cada lote, conforme os usos existentes e propostos (Figura 16). 


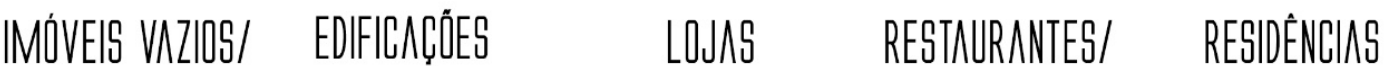 SUBUTLLIZADOS ESPECINS}

$\begin{array}{lllll} & & & & \\ & & & & \\ \text { - Ocupação com uso } & \text { - Igrejas, Ed. Públicos. } & \text { - Ampliar os horários } & \text { - Ampliar os horários } & \text { - Manter as } \\ \text { misto e fachadas } & \text { - Serão descritos nos } & \text { de funcionamento } & \text { de funcionamento } & \text { fachadas sempre } \\ \text { ativas. } & \text { detalhes de acordo } & \text { até as } 22 \mathrm{~h}, & \text { até as } 22 \mathrm{~h} \text { e/ou } & \text { interessantes, com } \\ \text { - IPTU Progressivo. } & \text { com as necessidades. } & \text { inserindo o conceito } & \text { oferecer serviço de } & \text { tratamentos e } \\ \text { - Incentivo fiscais às } & \text { Ex: Retirada de muro } & \text { de "shopping } & \text { bar ou atividades } & \text { revestimentos que } \\ \begin{array}{l}\text { atividades culturais } \\ \text { conectadas ao uso }\end{array} & \text { ou grades. } & \text { aberto". } & \text { culturais, como } & \text { embelezem o } \\ \text { residencial e misto! } & & & \text { shows e exposições, espaço público. } & \text { no período noturno. }\end{array}$

Figura 16 - Escala de cores que representará as soluções para as fachadas ativas. Fonte: Elaborada pelos autores (2019).

\section{Cenário 1 - Rua Duque de Caxias}

A rua Duque de Caxias é uma significativa via localizada na área de tombamento do Centro Histórico de João Pessoa (CHJP). Segundo Scocuglia (2017, p. 04), ela “[...] preserva características remanescentes de sua fundação, como a ortogonalidade das quadras, a ocupação das esquinas e a forma dos lotes urbanos coloniais - grande profundidade em detrimento da pequena dimensão presente nas testeiras dos terrenos". Essa via abriga ainda um comércio movimentado, com diversas lojas e restaurantes; é nela que está instalado um dos edifícios-chave do bairro, o Shopping Popular Terceirão.

A rua possui uma extensão aproximada de $800 \mathrm{~m}$, com calçadas que variam de 1,5 m até 4,5 m, enquanto os espaços destinados aos veículos alternam de $6 \mathrm{~m}$ a $8 \mathrm{~m}$, apresentando uma parte de seu percurso pedestrianizado. Para a observação comportamental e contagem do fluxo de pessoas (Figura 17), dividiu-se essa rua em três portais - 1, 2 e 3 -, percebendo-se que a ocupação nessa avenida ocorre de três formas distintas.

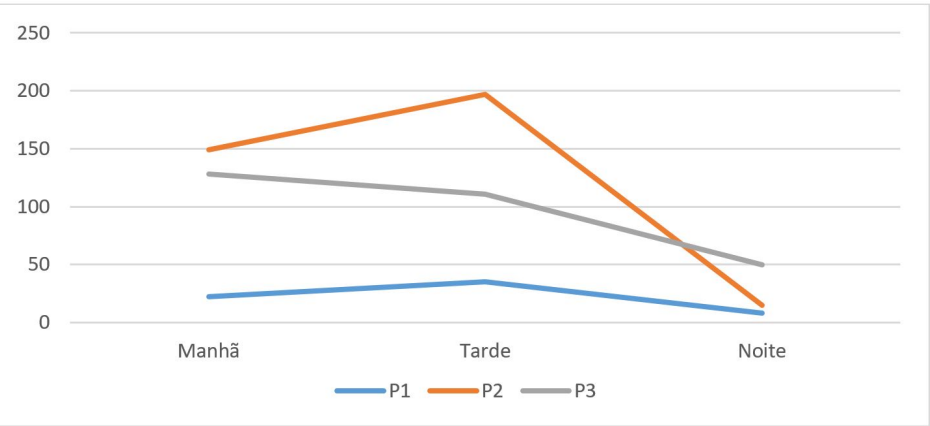

Figura 17 - Contagem do fluxo de pessoas na rua Duque de Caxias. Fonte: Elaborada pelos autores (2019).

No portal 1 (Figura 18), observou-se a maior quantidade de lotes ocupados apenas com residências, o que promove uma movimentação de pessoas menor durante o dia. No período matutino, a via é ocupada dos dois lados por estacionamento, que, combinado com a falta de "olhos da rua", gerou uma sensação de insegurança nos pesquisadores - o que não aconteceu nos demais portais. Observou-se a permanência de dois homens, que se dispõem a lavar e cuidar dos carros, e uma mulher do Sistema Zona Azul, responsável por gerenciar/fiscalizar o sistema de estacionamento nas vias urbanas e logradouros públicos. 


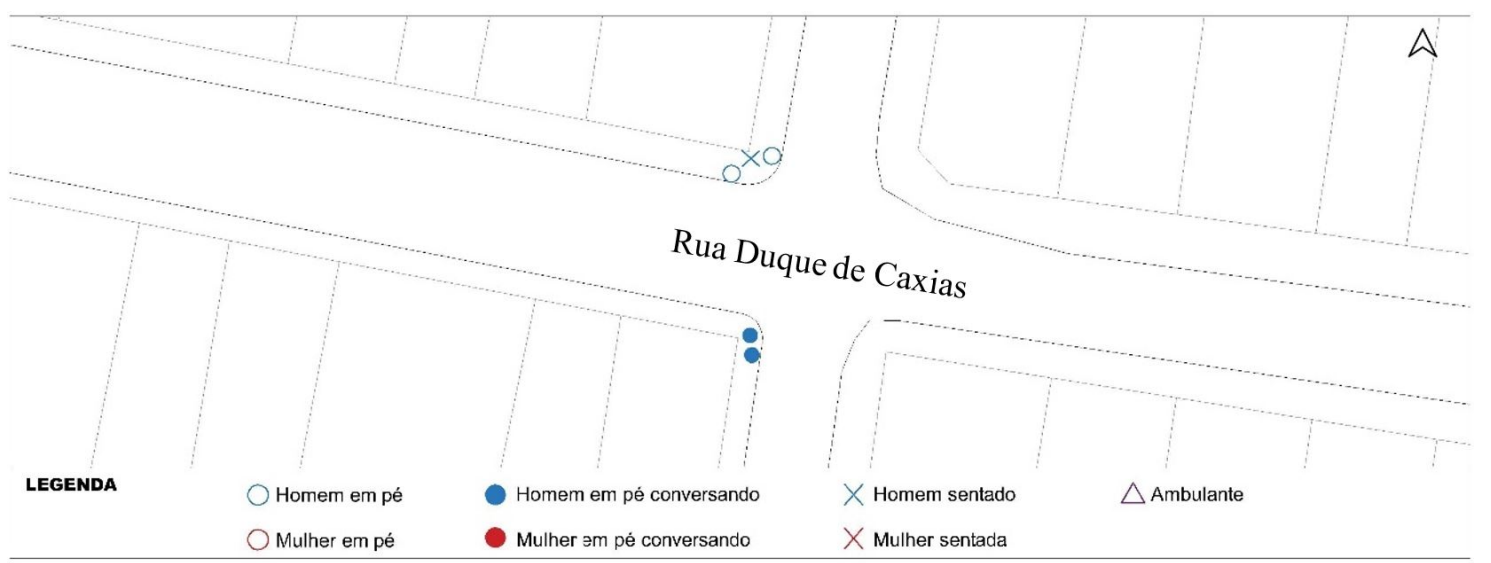

Figura 18 - Posição das pessoas localizadas na área do Pl durante o dia. Fonte: Elaborada pelos autores (2019).

No portal 2 (Figura 19), estão localizadas lojas e o Shopping Popular Terceirão, que proporcionam uma movimentação de pedestres maior, porém apenas em seus horários de funcionamento - manhã e tarde; e no portal 3 (Figura 20), situa-se a parte pedestrianizada da avenida, que se integra com a praça Vidal de Negreiros, recebendo um fluxo alto de pessoas. Ainda no portal 3, situa-se a praça João Pessoa, na qual se pôde notar a permanência de pessoas apenas nas áreas sombreadas e com mobiliário - em pouca quantidade e inadequada manutenção -, enquanto a via, ocupada por estacionamentos dos dois lados, apresentou um caráter prioritariamente de passagem. É interessante ressaltar que se constatou a presença de vários ciclistas nos portais 2 e 3, mas nenhum no portal 1.

No período noturno, acontece na praça João Pessoa e na praça Vidal de Negreiros a distribuição de alimentos para moradores de rua, por volta das 19 às $21 \mathrm{~h}$, que movimenta o local, porém, nas demais imediações, a rua fica vazia, com presença de pessoas apenas na frente de um bar localizado no final da avenida.

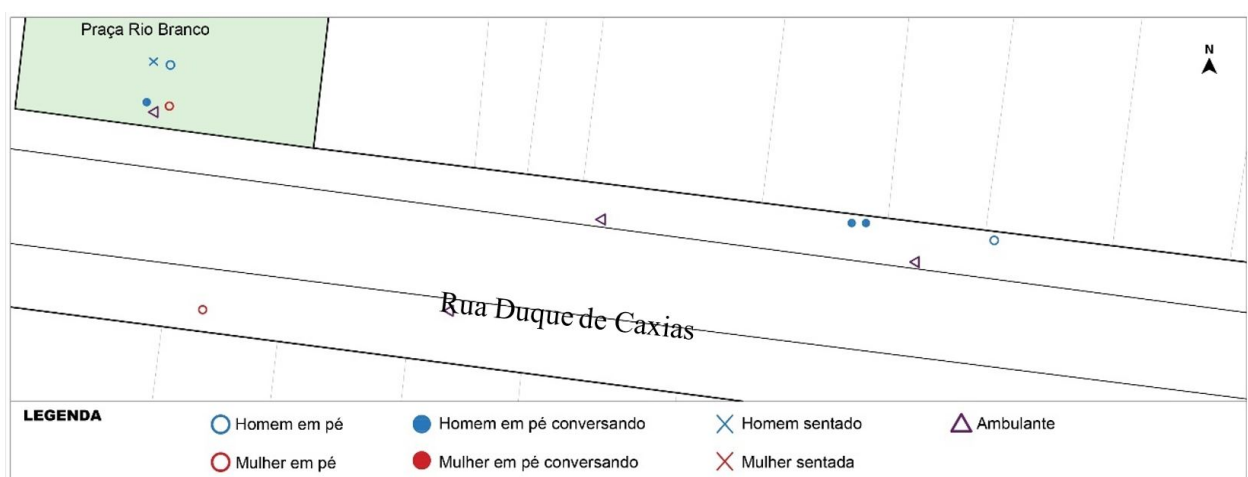

Figura 19 - Posição das pessoas localizadas na área do P2 durante o dia. Fonte: Elaborada pelos autores (2019).

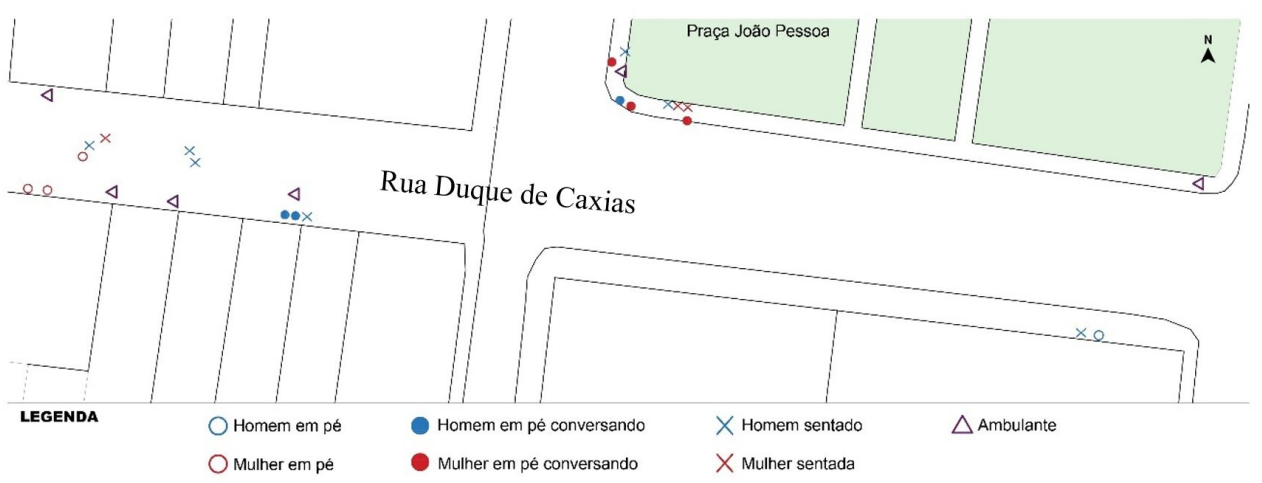

Figura 20 - Posição das pessoas localizadas na área do P3 durante o dia. Fonte: Elaborada pelos autores (2019). 
Depois das análises, iniciou-se a proposta para o espaço público considerando as questões observadas no levantamento (Figuras 21 e 22). Analisando, a princípio, as calçadas, optou-se por utilizar $0,70 \mathrm{~m}$ de faixa de transição, a fim de incentivar a expansão das atividades de comércios e moradias para elas, como o uso de mesas e cadeiras ao ar livre, mantendo sempre "olhos na rua". Na faixa de serviço, propôs-se a dimensão de $1 \mathrm{~m}$, para que seja possível a inserção de vegetação e mobiliários que incentivem a permanência dos pedestres. Em relação aos transportes, projetou-se uma ciclovia unidirecional de 1,20 m para dar suporte à demanda existente; já a pista de rolamento foi planejada com 3,50 m, para que os automóveis percorram com uma velocidade máxima de $30 \mathrm{~km} / \mathrm{h}$.
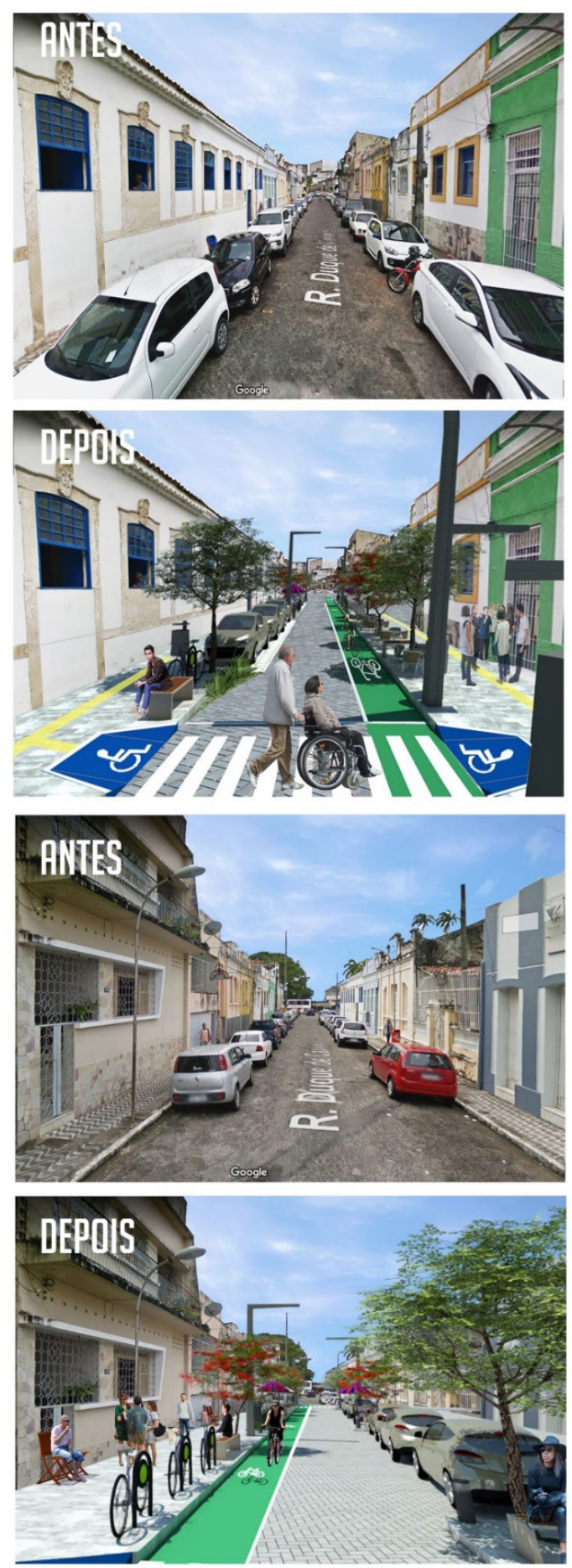

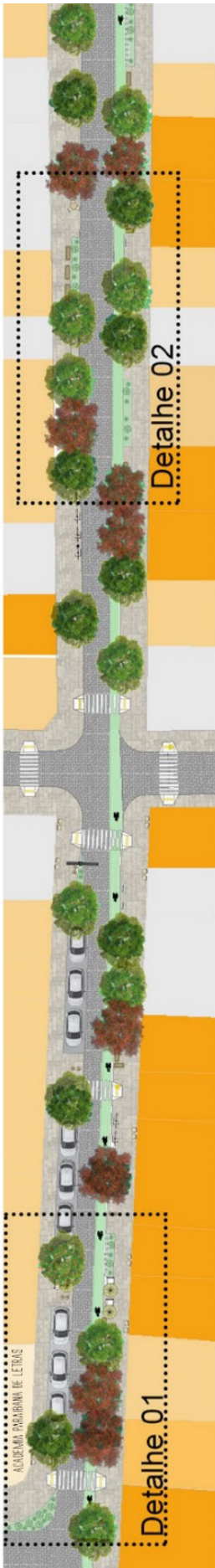

Figura 21 - Proposta de uma Rua Completa na rua Duque de Caxias. Fonte: Elaborada pelos autores (2019). 

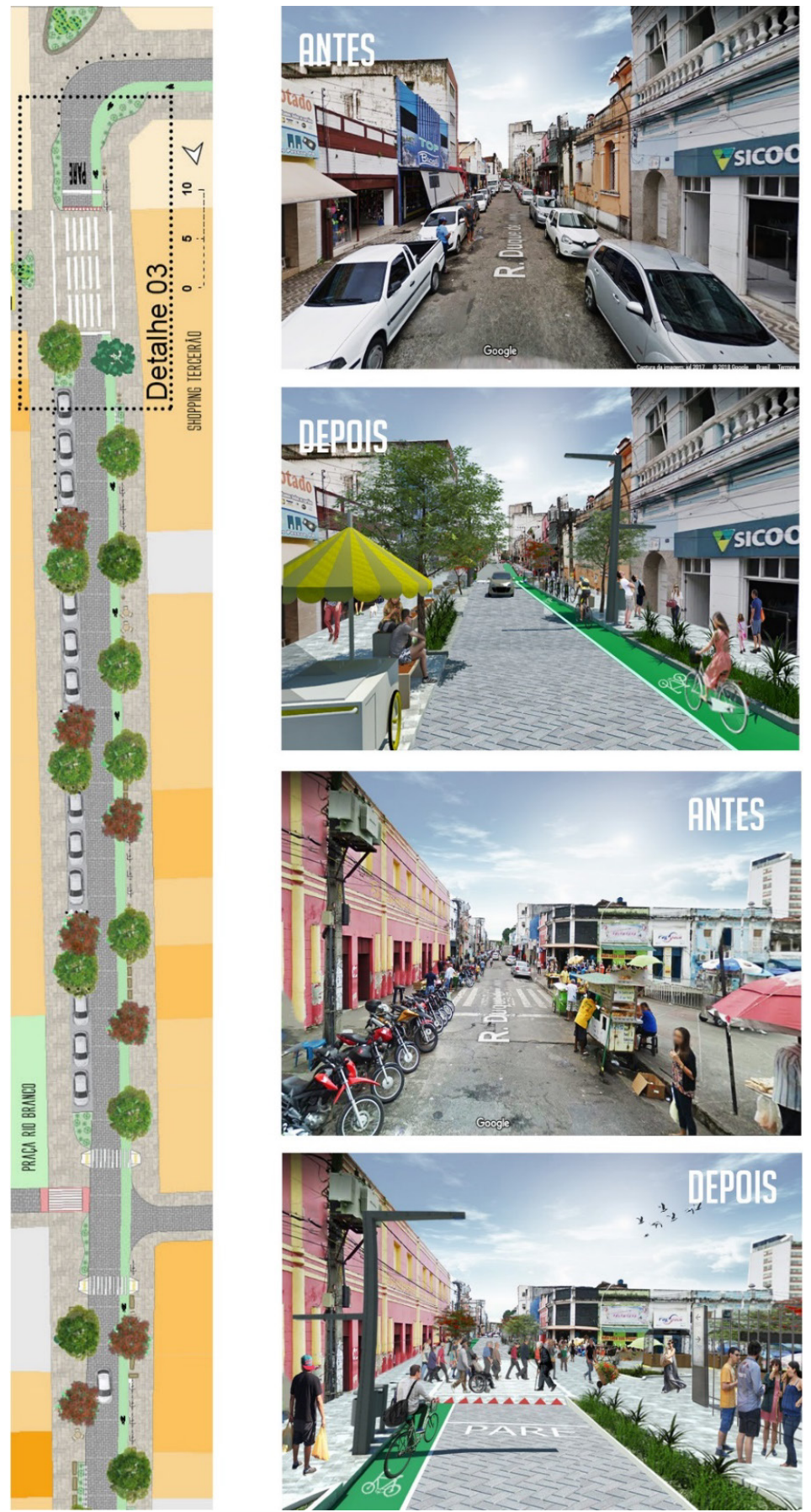

Figura 22 - Proposta de uma Rua Completa na rua Duque de Caxias. Fonte: Elaborada pelos autores (2019).

Na área do portal 1 (Figura 23), inseriram-se locais de estacionamento para os moradores, diminuindo a faixa de rolamento dos carros para 2,50 m, possibilitando a entrada apenas de automóveis pequenos e com baixa velocidade. No portal 2 (Figura 24), também se implantaram alguns estacionamentos ao longo da via, porém apenas nos locais em que ela apresenta uma largura maior; onde não há estacionamento, as calçadas foram ampliadas para $4 \mathrm{~m}$ de largura. É importante ressaltar que os estacionamentos, máximos de $15 \mathrm{~m}$ de extensão, foram alterados para $10 \mathrm{~m}$ de calçadas, sendo implantados bancos e árvores, e deixando espaços livres para ambulantes, sem causar conflitos com a faixa livre dos pedestres. Na entrada do Shopping Terceirão (Figura 25), propôs-se a instalação de uma faixa de pedestre elevada, aumentando a atenção dos motoristas nesse local. 


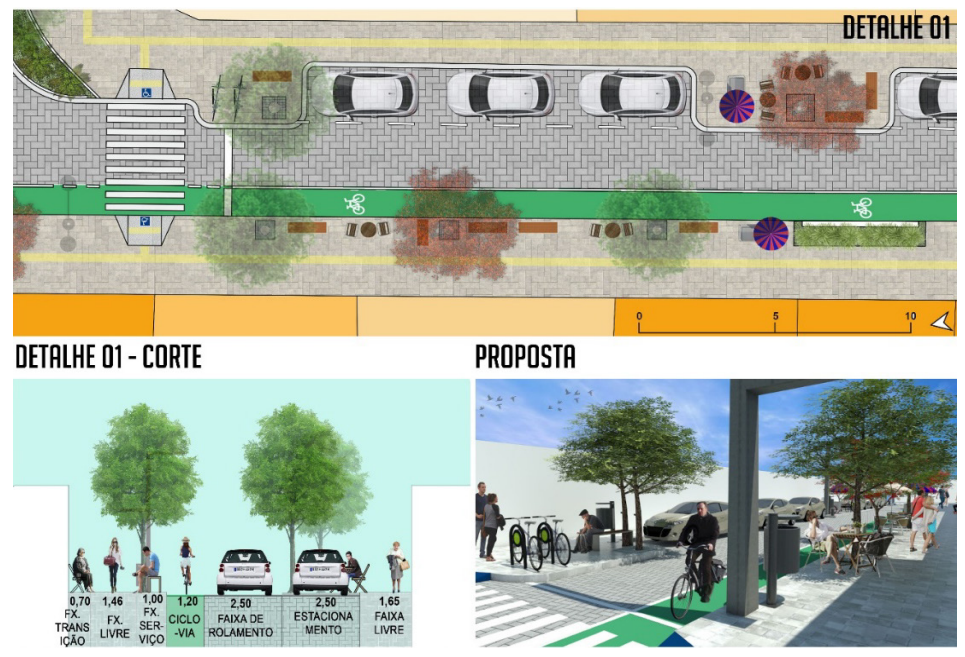

Figura 23 - Detalhe 01 da proposta para rua Duque de Caxias. Fonte: Elaborada pelos autores (2019).

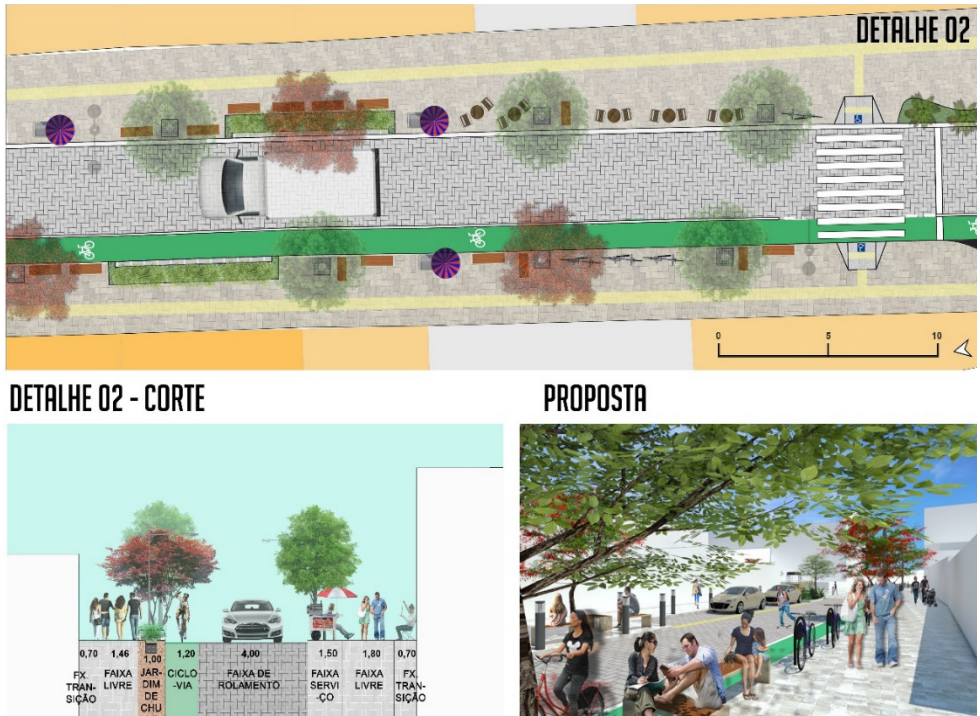

Figura 24 - Detalhe 02 da proposta para rua Duque de Caxias. Fonte: Elaborada pelos autores (2019).
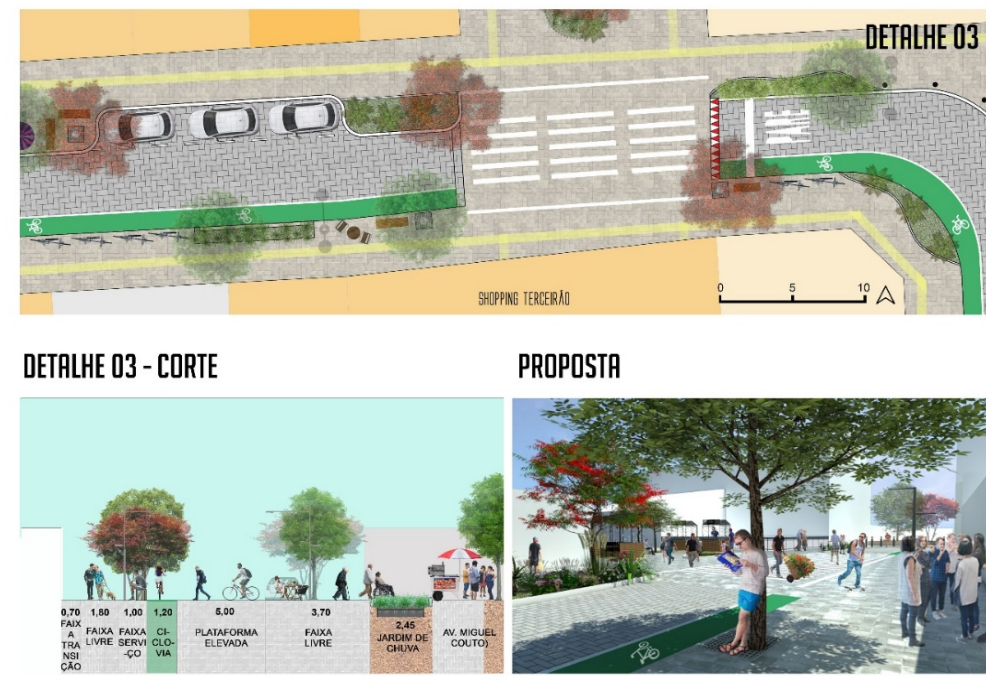

Figura 25 - Detalhe 03 da proposta para rua Duque de Caxias. Fonte: Elaborada pelos autores (2019). 


\section{Cenário 2 - Rua Santo Elias}

A rua Santo Elias possui um caráter predominantemente comercial e interliga o Shopping Tambiá ao parque da Lagoa, possuindo quase todas as fachadas limítrofes à rua, uma vez que a maior parte dos lotes não apresenta recuo frontal ou lateral. Ainda possui terrenos abandonados ou subutilizados. As calçadas são estreitas para atender ao grande fluxo de pedestres e ambulantes, e, ao longo de toda a sua extensão, há estacionamento em uma das laterais da pista de rolamento.

Durante a análise comportamental, pôde-se notar que essa rua apresentou a maior movimentação de pedestres, chegando a um fluxo aproximado de 40 pessoas por minuto (Figura 26). Por se tratar de uma avenida de curta extensão, estabeleceram-se dois portais. Assim, considerou-se como entrada a extremidade mais próxima do parque da Lagoa, portal 5 (Figura 27), e como saída, a mais próxima do Shopping Tambiá, portal 4 (Figura 28). Durante o período de contagem, observou-se uma maior chegada e permanência de pessoas na rua e edificações existentes (possivelmente pontos de trabalho) pela manhã; uma maior partida de pessoas da rua e edificações existentes (possivelmente, por causa do término do expediente de trabalho) à tarde; e pouca presença e permanência de pessoas no turno da noite.

Um dos problemas mais notório dessa rua é que ela possui um grande volume de ambulantes na calçada - 41 ambulantes contados no período diurno -, além de as próprias lojas invadirem a calçada com expositores, o que diminui ainda mais o espaço de passagem dos pedestres. Outro problema é o grande fluxo de veículos, que, combinado com o estacionamento em um lado da via, diminui o espaço dos transeuntes, além de tornar mais perigosa a travessia dos caminhantes.

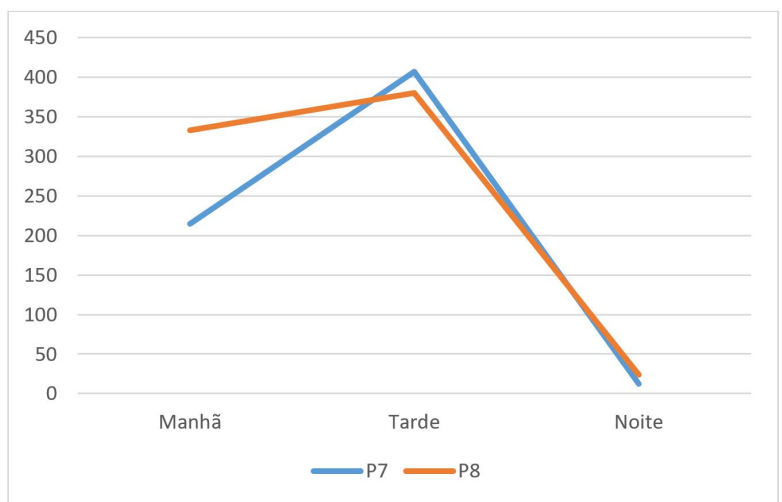

Figura 26 - Contagem do fluxo de pessoas na rua Santo Elias. Fonte: Elaborada pelos autores (2019).

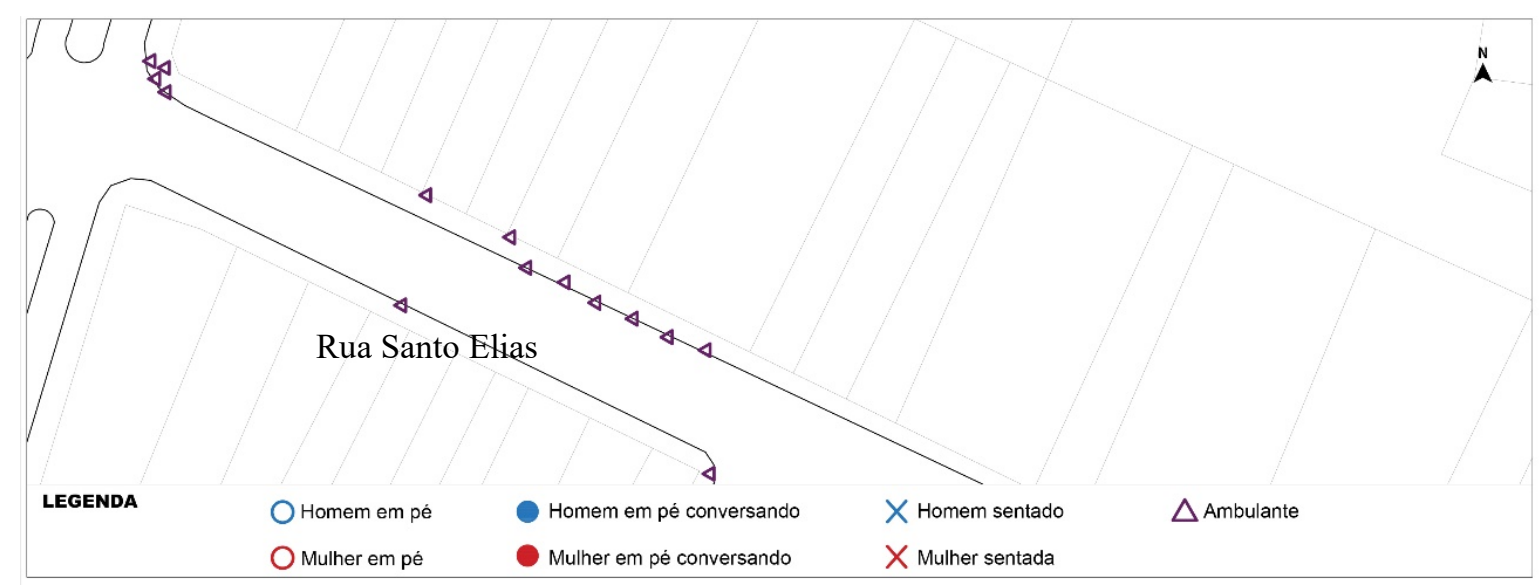

Figura 27 - Posição de todas as pessoas localizadas na área do P4 durante o dia. Fonte: Elaborada pelos autores (2019). 


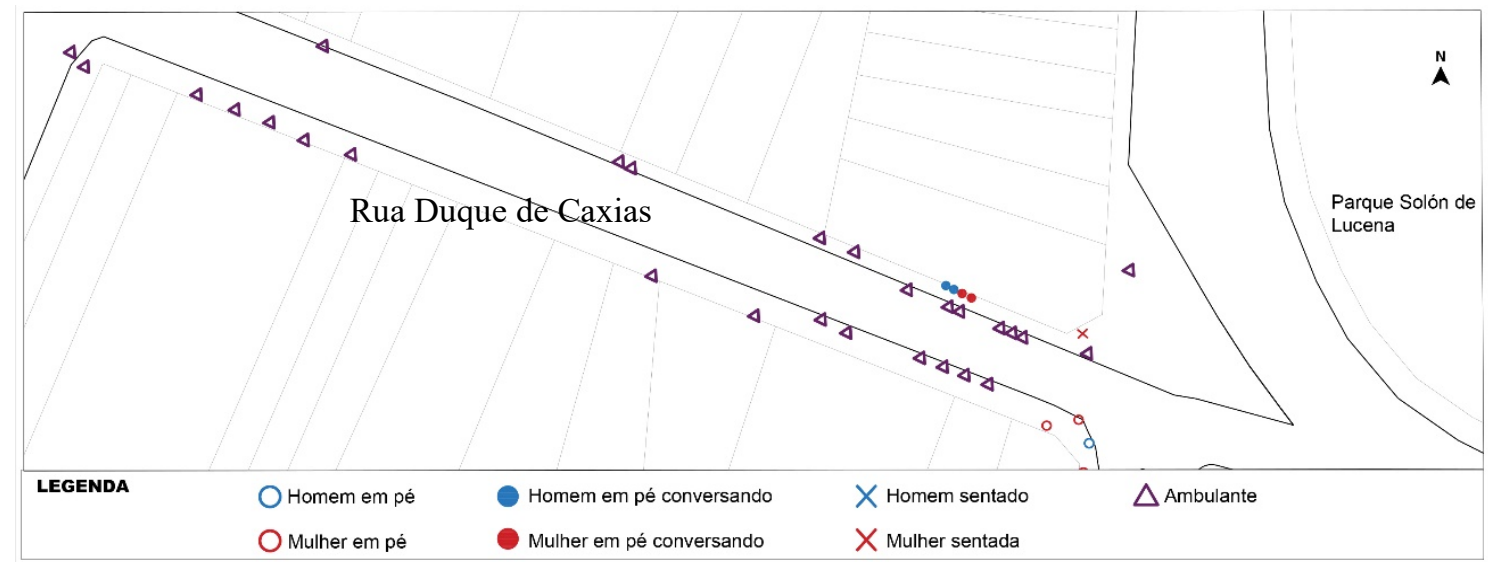

Figura 28 - Posição de todas as pessoas localizadas na área do P5 durante o dia. Fonte: elaborada pelos autores (2019).

A proposta da rua Santo Elias (Figura 29) consiste em torná-la apenas para pedestres e ciclistas, pois, de acordo com levantamento realizado, ela não apresenta dimensão suficiente para compartilhar os fluxos dos todos os modos de transporte em razão do grande número de pedestres. Prevê-se que a proposta de intervenção promova baixo impacto quanto ao deslocamento de automóveis, uma vez que as suas dimensões atuais impossibilitam o deslocamento de transporte coletivo e dificultam a circulação dos automóveis individuais.

Dessa forma, o projeto buscou tornar a rua compartilhada entre pedestres e ciclistas, criando espaços de permanência com mobiliários e arborização (Figuras 30 e 31), além de padronizar e uniformizar as calçadas com superfícies em blocos intertravados, elevando até o nível de entrada das lojas e inserindo piso tátil, a fim de garantir condições de acessibilidade adequadas a qualquer pessoa.

Para solucionar os problemas dos ambulantes na rua, propôs-se a solução citada anteriormente sobre a organização deles, com o uso das Faixas Amarelas, organizadas de forma alternada, a criar obstáculos para que os ciclistas não alcancem altas velocidades. Propuseram-se também quiosques uniformizados para manter o equilíbrio e organização na paisagem da via. Com a disposição desses quiosques, será possível a instalação de 43 ambulantes fixos no calçadão, além de prover de espaços livres para ambulantes móveis que estejam de passagem. É importante preservar esses ambulantes no espaço público viário, pois eles mantêm a dinâmica de ocupação das avenidas e atraem mais pedestres para o local. 

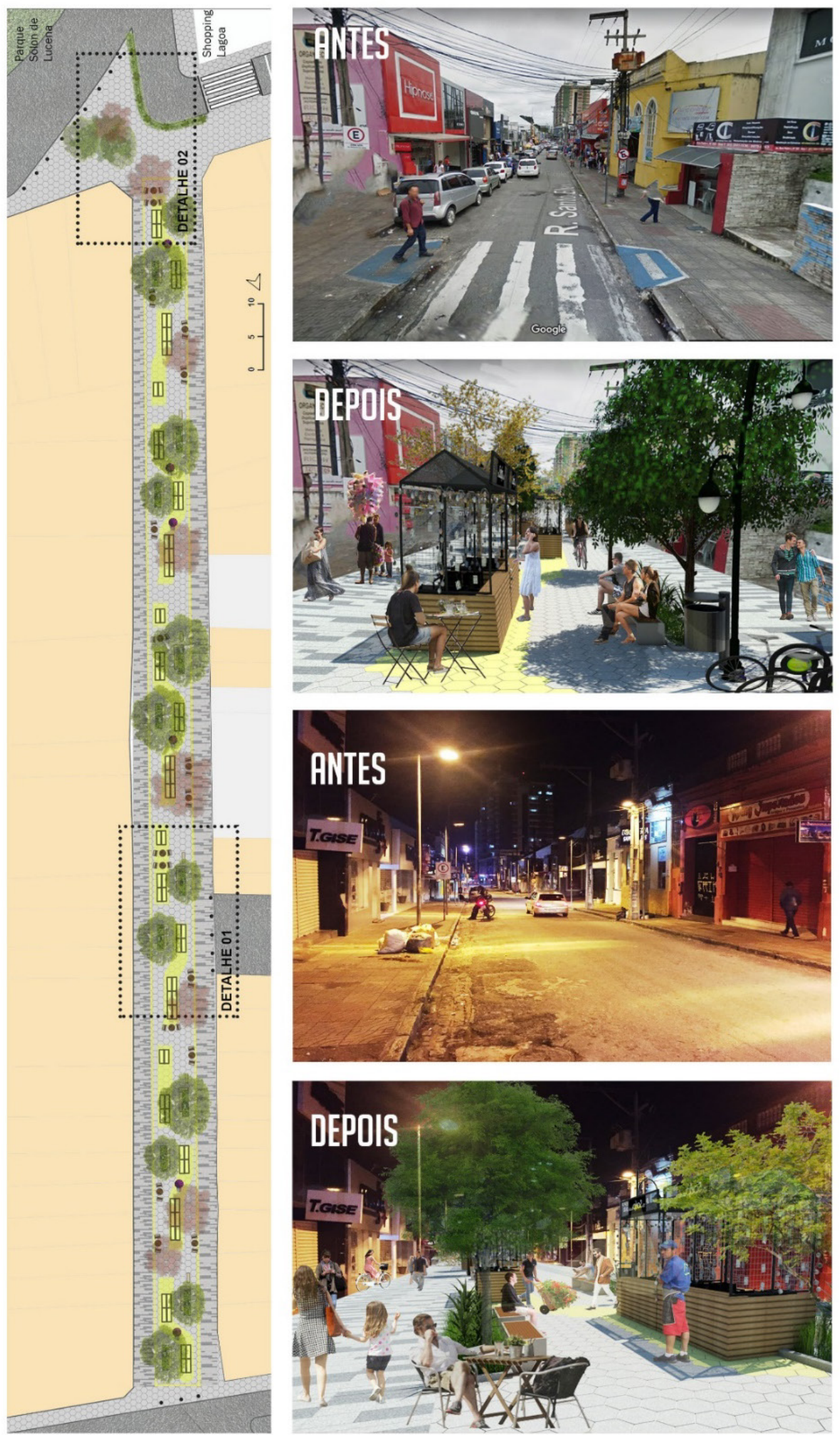

Figura 29 - Proposta de uma Rua Completa para rua Santo Elias. Fonte: Elaborada pelos autores (2019). 

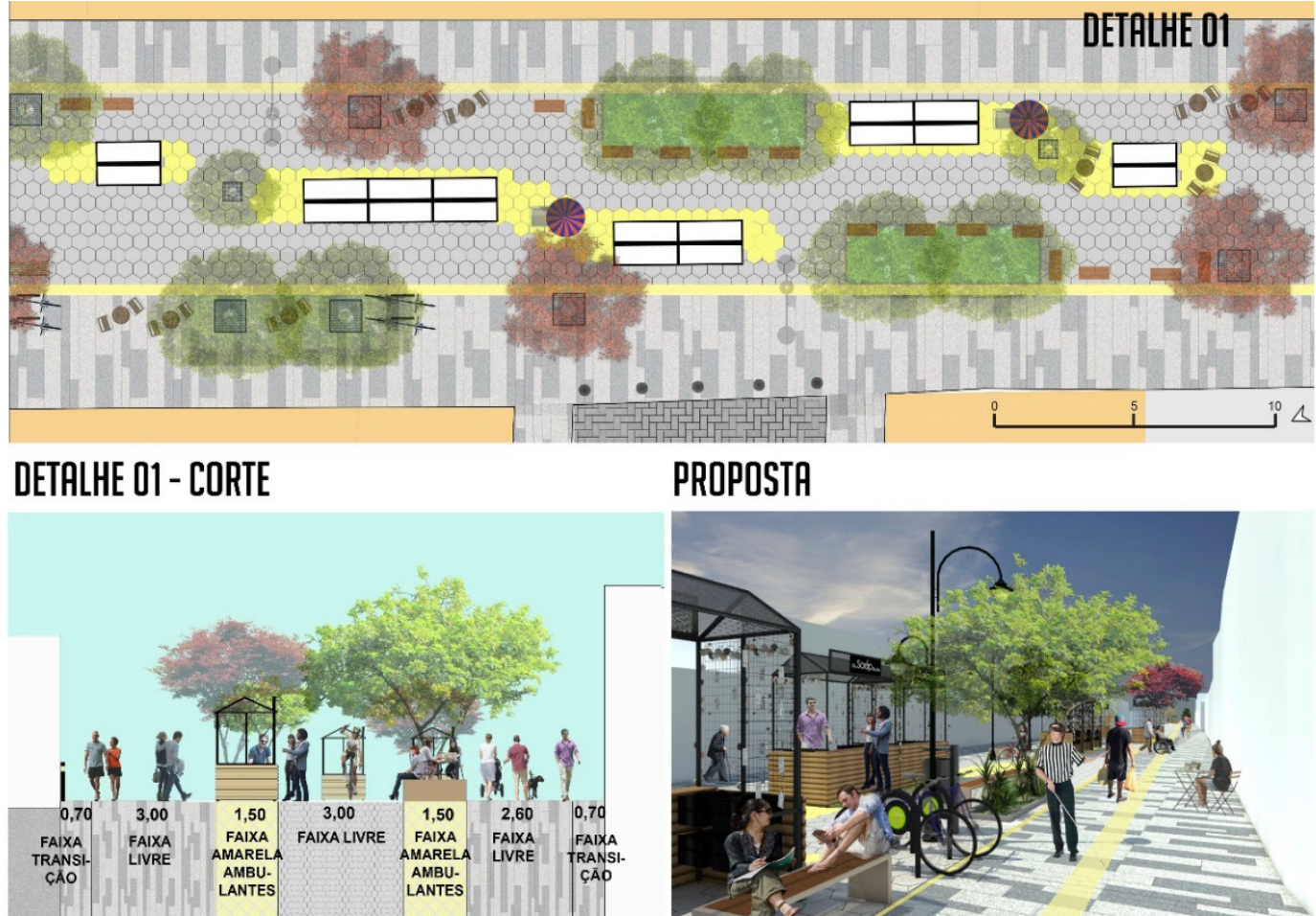

\section{PROPOSTH}

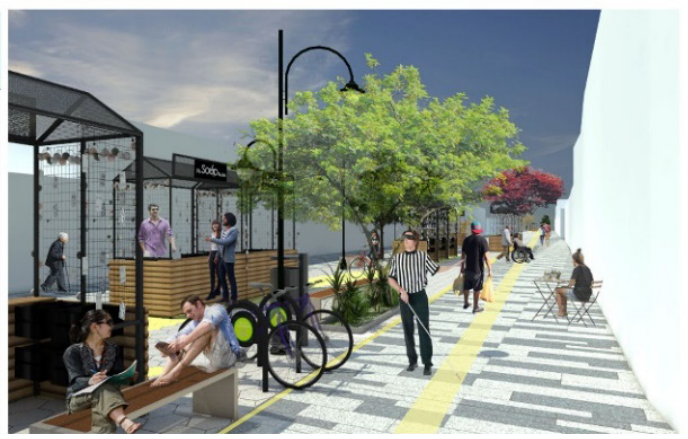

Figura 30 - Detalhe 01 da proposta para rua Santo Elias. Fonte: elaborada pelos autores (2019).

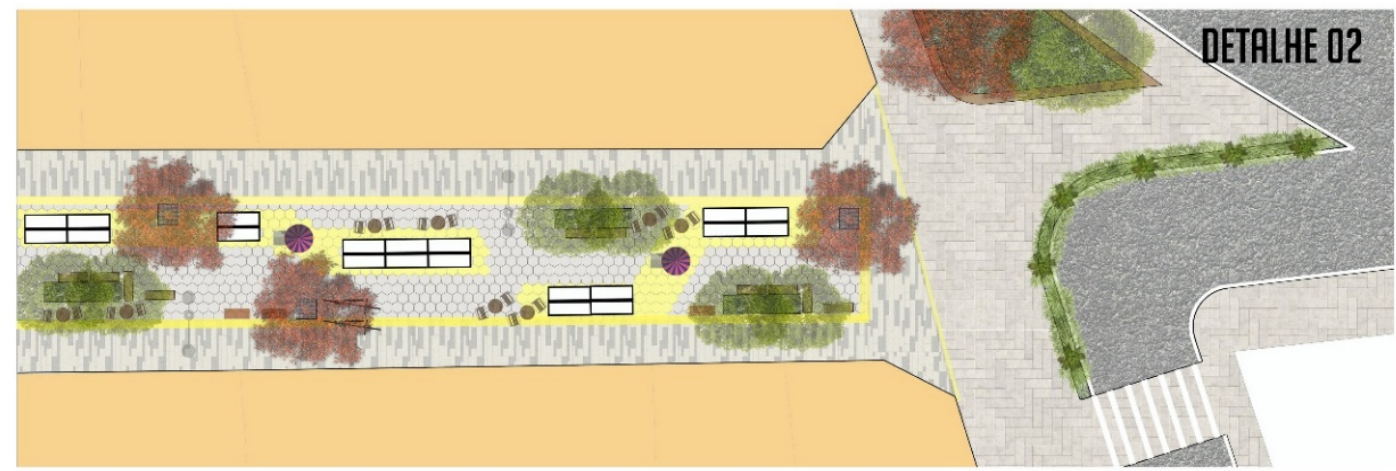

PROPOSTR

\section{PROPOSTR}
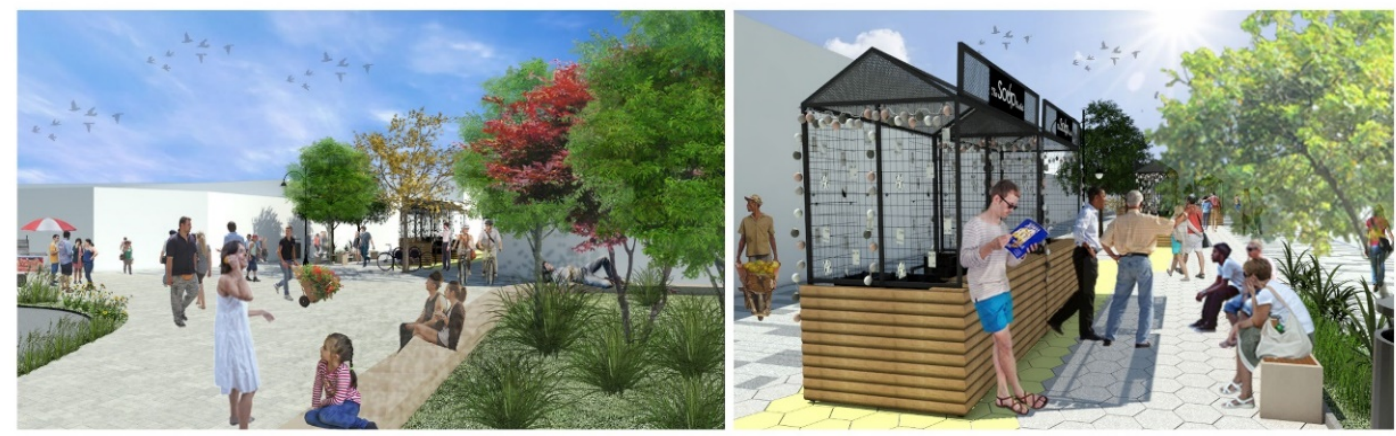

Figura 31 - Detalhe 02 da proposta para rua Santo Elias. Fonte: Elaborada pelos autores (2019). 


\section{Considerações finais}

O presente trabalho surgiu da inquietação aos modos antiquados de uso dos espaços viários de João Pessoa/PB, cidade conduzida prioritariamente pela inserção do suposto rápido e livre trânsito dos veículos motorizados individuais, o que levou os autores deste artigo a buscar novas alternativas e soluções para esse problema. Assim, considerar o conceito de Ruas Completas foi uma decisão importante, pois, embora o tema seja recente, os seus objetivos podem fomentar a mudança do pensamento de planejar cidades, especialmente as áreas centrais.

A utilização de modos de transportes sustentáveis e de caminhada vem, ao longo dos anos, sendo negligenciada, o que promove a reação de ativistas, da própria população e de gestores públicos a buscar soluções que revertam essa visão. 0 desenvolvimento deste trabalho sugere soluções a partir de conceitos que visam trazer o pedestre como prioridade no planejamento das cidades, motivando a criação de ambientes convidativos à sua permanência - considerando a sua dinâmica local - de forma a minimizar os impactos causados pelos automóveis, tanto no meio ambiente quanto na vitalidade das cidades.

Esses conceitos foram aqui aplicados enfocando a ampliação ou pedestrianização de ruas da área central da cidade objeto de estudo, a fim de enfatizar avenidas destinadas a pedestres e ciclistas, oferecendo espaços suficientes para atender aos altos fluxos de caminhantes, assim como incentivar a permanência deles no espaço público, por meio de locais arborizados, oferta de mobiliários e multiplicação do uso misto, a partir do resgate do uso residencial, utilizado em conjunto com o comércio e serviço - uma vocação da área -, por meio de instrumentos da Lei no 10.257 , como o IPTU progressivo e a outorga onerosa.

Ao longo das análises "in loco", observou-se que as atividades dos ambulantes podem ser caracterizadas como uma identidade do local, fator importante para a proposta, uma vez que se optou pela permanência deles, porém de maneira ordenada, a fim de mitigar os problemas de acessibilidade e mobilidade nas calçadas causados por eles.

A proposta apresentada busca destacar a importância de incluir diferentes dimensões viárias nas políticas de planejamento urbano de João Pessoa - especialmente sua área central, de forma que a distribuição do espaço público seja mais democrática, atendendo a perfis variados de usuários. É preciso inverter o ideal de desenvolvimento social por meio de grandes avenidas desumanas para aquele em que a população possa participar de forma ativa e emocional no cotidiano urbano, criando espaços vibrantes, propícios ao desenvolvimento da economia local e incentivando a população a ter hábitos mais saudáveis. E nada melhor do que começar por onde a cidade foi fundada: o bairro Centro.

\section{Referências}

Andrade, P. A. F., Ribeiro, E. L., \& Silveira, J. A. R. (2009). Centralidade urbana na cidade de João Pessoa-PB: uma análise dos usos comerciais e de serviços entre o centro tradicional e o centro seletivo-1970/2006 (Vol. 9). São Paulo: Arquitextos.

Brito, H. C. (2012). A receptividade do traffic calming no Bairro de Manaíra, João Pessoa-PB. (Dissertação de mestrado). Programa de Pós-graduação em Engenharia Urbana e Ambiental, Universidade Federal da Paraíba, João Pessoa.

Corrêa, R. (1989). O espaço urbano. São Paulo: Ática.

Figueiredo, L. (2010). Desurbanismo: um manual rápido de destruição de cidades. In Anais do I ENANPARQ. Rio de Janeiro: ANPARQ.

Gehl, J. (2013). Cidades para pessoas. São Paulo: Perspectiva.

Gehl, J., \& Svarre, B. (2013). How to study public life. Washington: Island Press. http://dx.doi.org/10.5822/978-1-

61091-525-0. 
Guedes, K. A., Tinem, N., \& Vidal, W. (2013). Rua do Tambiá: transformações contemporâneas no Centro Histórico de João Pessoa. In Anais do $4^{\circ}$ Arquimemória. Salvador: IAB.

Hillier, B., \& Hanson, J. (1984). The social logic of space. Cambridge: Cambridge University Press. http://dx.doi.org/10.1017/CB09780511597237.

Instituto Brasileiro de Geografia e Estatística - IBGE. (2010). Censo demográfico 2010. Rio de Janeiro: IBGE. Recuperado em 20 de março de 2018, de www.ibge.gov.br

Jacobs, J. (2013). Morte e vida das grandes cidades (3. ed.). São Paulo: WMF Martins Fontes.

João Pessoa. Prefeitura Municipal. (1992). Plano diretor da cidade de João Pessoa. Recuperado em 20 de março de 2018, de http://www.joaopessoa.pb.gov.br/secretarias/seplan/plano-diretor/

João Pessoa. Prefeitura Municipal. (2009). Decreto N. 6.499 de 20 de março de 2009. Recuperado em 22 de julho de 2020, de http://antigo.joaopessoa.pb.gov.br/portal/wpcontent/uploads/2012/04/planodiretor2009.pdf/.

João Pessoa. Prefeitura Municipal. (2012). Plano cicloviário de João Pessoa. Recuperado em 20 de março de 2018, de http://www.joaopessoa.pb.gov.br/secretarias/semob/pac-mobilidade-urbana/

João Pessoa. Prefeitura Municipal. (2014). Plano de ação João Pessoa sustentável. Recuperado em 20 de março de 2018, de http://polis.org.br/wp-content/uploads/Plano_de_Acao_Joao_Pessoa_ICES.pdf

Karssenberg, H., Laven, J., Glaser, M., \& Hoff, M. V. (2015). A cidade ao nível dos olhos: lições para os plinths. Porto Alegre: EDIPUCRS.

Negrão, A. G., \& Silveira, J. A. R. (2016). Conjuntos habitacionais populares e periferização: a produção e apropriação do setor sudeste de João Pessoa/Paraíba. In A. Silva, M. D. Silva, \& J. A. R. Silveira (Eds.), Lugares e suas interfaces intraurbanas: transformações urbanas e periferizações. João Pessoa: UFPB.

São Paulo. (2014). Plano Diretor Estratégico do Município de São Paulo. Recuperado em 20 de março de 2018, de https://gestaourbana.prefeitura.sp.gov.br/arquivos/PDE-Suplemento-

Scocuglia, J. B. C. (1999). A política habitacional do BNH no Brasil pós-64 e seus reflexos na expansão urbana de João Pessoa. João Pessoa: Editora Universitária/UFPB.

Scocuglia, J. B. C. (2017). Cidades, intervenções e práticas urbanas: usos do espaço público e qualidade sociourbanística nos centros de João Pessoa e Recife. Recuperado em 20 de março de 2018, de https://leccur.wordpress.com/2017/08/23/page/2

Silva, E. R. (2016). Centro Antigo de João Pessoa: forma, uso e patrimônio edificado (Dissertação de mestrado). Universidade Federal do Rio Grande do Norte, Natal.

Silva, G. J. A., \& Romero, M. A. B. (2015). Sustentabilidade urbana aplicada: análise dos processos de dispersão, densidade e uso e ocupação do solo para a cidade de Cuiabá, Estado de Mato Grosso, Brasil. EURE. Revista Latinoamericana de Estudios Urbano Regionales, 41(122), 209-237. http://dx.doi.org/10.4067/S025071612015000100010 .

Silva, G. J. A., Silva, S. E., \& Nome, C. A. (2016). Densidade, dispersão e forma urbana: dimensões e limites da sustentabilidade habitacional. Arquitextos, 16(189.07). Recuperado em 20 de março de 2018, de http://www.vitruvius.com.br/revistas/read/arquitextos/16.189/5957

Speck, J. (2017). Cidade caminhável (A. Dimarco, \& A. Natividade, Trad.). São Paulo: Perspectiva.

Universidade Federal da Paraíba - UFPB. Laboratório do Ambiente Urbano e Edificado - LAURBE. (2010).

Relatório do índice de qualidade de vida urbana de João Pessoa, Paraíba (IQVU/JP/PB). João Pessoa.

Vaughan, L. (2001). Space Syntax observation manual. London: Space Sintax.

Villaça, F. (2001). Epaço intraurbano no Brasil: esse desconhecido. São Paulo: Studio Nobel.

WRI Brasil. (2017). Ruas completas dão vida e segurança aos espaços urbanos. Recuperado em 24 de agosto de 2017, de http://wricidades.org/noticia/ruas-completas-dao-vida-e-seguranca-aos-espacos-urbanos 
WRI Cidades. (2017). Afinal, o que são ruas completas? Recuperado em 24 de dezembro de 2017, de http://wricidades.org/noticia/afinal-o-que-sao-ruas-completas

Zavestoski, S., \& Agyeman, J. (2015). Complete streets: what is missing? In S. Zavestoski, \& J. Agyeman (Eds.), Incomplete streets: processes, practices, possibilities. New York: Routledge.

Zmitrowicz, W., De Angelis, G., No. (1997). Infra-estrutura urbana (Textos Técnicos). São Paulo: POLI-USP.

Editor: Fábio Duarte

Recebido: Jun. 11, 2019

Aprovado: Mar. 30, 2020 